\title{
The First Results of the Project on Restoration of Genetic Diversity of the Saker Falcon Populations in the Altail-Sayan Region, Russia
}

\section{ПЕРВЫЕ РЕЗУЛЬТАТЫ ПРОЕКТА ПО ВОССТАНОВЛЕНИЮ ГЕНЕТИЧЕСКОГО РАЗНООБРАЗИЯ ПОПУЛЯЦИЙ БАЛОБАНА В АЛТАЕ-САЯНСКОМ РЕГИОНЕ, РОССИЯ}

\author{
Karyakin I.V. (Center of Field Studies, N. Novgorod, Russia) \\ Zinevich L.S., Rozhkova D.N. (Koltzov Institute of Developmental Biology of Russian \\ Academy of Sciences, Moscow, Russia) \\ Nikolenko E. G., Shnayder E.P. (Sibecocenter LLC, Berdsk, Novosibirsk region, Russia) \\ Sarychev E.I. ("Vitasfera" LLC, Moscow, Russia) \\ Beme I.R. (Lomonosov Moscow State University, Moscow, Russia) \\ Карякин И.В. (Центр полевых исследований, Н.Новгород, Россия) \\ Зиневич Л.С., Рожкова Д.Н. (ФГБУН Институт биологии развития им. Н.К. Кольцова \\ РАН, Москва, Россия) \\ Николенко Э.Г., Шнайдер Е.П. (ООО «Сибэкоцентр», Бердск, Новосибирская \\ область, Россия) \\ Сарычев Е.И. (ООО «Витасфера», Москва, Россия) \\ Бёме И.Р. (МГУ им. М.В. Ломоносова, Москва, Россия)
}

\section{Контакт: \\ Игорь Карякин \\ Центр полевых \\ иссиецований \\ 603109, Россия, \\ г. Нижний Новгород, \\ ул. Нижегородская, 3-29 \\ тел.: +7831433 3847 \\ ikar_research@mail.ru \\ ヘюдмила Зиневич ФГБУН ИНСтитут \\ биологии развития им. Н.К. КольцОва РАН 119334, Россия, \\ Москва, \\ ул. Вавилова, 26 \\ тел.: +7 49913533 22, \\ фракс: +74991358012 \\ Izinevich@gmail.com}

Аарья Рожкова ФГБУН Институт биологии развития им. Н.К. Кольцова РАН 119334, Россия, Москва,

ул. Вавилова, 26 тел.: + 79017439525 darroznature@ gmail.com

Эльвира Николенко, ООО “Сибэкоцентр" 630090, Россия, Новосибирск, а/я 547

тел.: +79231501279 elvira_nikolenko@mail.ru www.sibecocentr.ru www.rrren.ru

\section{Резюме}

Летом 2017 г. в Алтае-Саянском регионе был реализован пилотный проект по выпуску в природу птенцов алтайской морфы балобана (Falco cherrug) путём подсаживания 10 выращенных в питомнике птенцов в естественные гнёзда балобанов Аругих морф. Молекулярные анамизы по определению последовательности контрольного региона (D-петли) митохондриального генома от 414 до 1417 ьр (1004 ьр) показали, что гаплотипы подсаженных птенцов из питомника в ряде случаев не отличались от таковых нативных птиц в естественных гнёздах, куда подсаживами птенцов, и соответствовами запанной и восточной гаплогруппам. $\Delta$ есять птенцов из питомника были рассажены по 6 гнёздам с 24 нативными птенцами. Видеонаблюдения

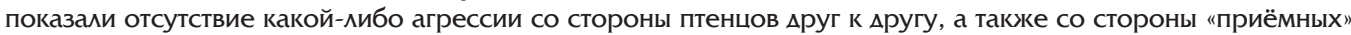
родителей. Отход птенцов Ао вылета из гнезда составил 4 птенца: 1 птенец из питомника и 1 нативный были добыты филином (Bubo bubo) на гнезде в Республике А^тай, 2 нативных птенца в $\Delta$ вух гнёздах в Туве погибли по разным причинам. Успешно вылетели из гнёзд 9 птенцов из питомника и 21 нативный. Отход после вылета составил 2 птенца: один нативный и один из питомника - оба были убиты более крупными пернатыми хишниками. Младшая самка из выводка в алтайском гнезде успешно ушла в миграцию и добралась до места зимовки в Монголии.

Кһючевые слова: пернатые хищники, хишные птицы, балобан, Falco cherrug, реинтродукция, молекулярные исследования, митохондриаиьный геном, Алтае-Саянский регион.

Поступима в реАакцию: 15.12.2017 г. Принята к публикации: 30.12.2017 г.

\section{Abstract}

On summer 2017 a pilot project on population recovery of Saker Falcon (Falco cherrug) was conducted in AltaiSayan region of Russia. Ten 20-days old falcons of "Altaic" morph from a breeding center were placed in nests of wild falcons of other color morphs. Sequence of control region (D-loop) of mitochondrial genome from 414 to 1417 bp (1004 bp) proofed that in particular cases haplotypes of non-native nestlings from the breeding center were similar to those of native falcons that acted as adoptive parents. Analysis also revealed that haplotypes of nestlings matched the previously determined western and eastern haplogroups. Ten nestlings from a breeding center were placed in 6 nests of wild Sakers with 24 native nestlings. Video-recording revealed no aggression between native and no-native nestlings, as well as no aggression from adult birds towards non-native nestlings. The losses before fledging amounted to 4 nestlings. One native and one non-native nestlings were killed on a nest by an Eagle Owl (Bubo bubo) in Altai Republic, and 2 native nestlings died for an unknown cause in Tyva Republic. In total, 9 non-native nestlings and 21 native nestlings successfully fledged and left the nests. The known losses after fledging amounted to 2 young birds - one native and one non-native, both were killed by bigger raptors. The youngest female from the nest in Altai Republic tagged with GPS-GSM tracker successfully migrates and winters now in Mongolia.

Keywords: birds of prey, raptors, Saker Falcon, Falco cherrug, reintroduction, molecular studies, mitochondrial genome, Altai-Sayan region.

Received: 15/12/2017. Accepted: 30/12/2017.

DOI: $10.19074 / 1814-8654-2017-35-176-192$ 
Елена Шнайдер ООО "Сибэкоцентр" 630090, Россия, Новосибирск, а/я 547

тел.: +79137956549 equ001@gmail.com

Евгений Сарычев ООО "Витасрера" 140170, Россия, Московская обл, Раменский район, А. Слободино vitasfera@mail.ru

Ирина Бёме Каседра зоологии позвоночных Биологического факультета Московского Государственного Университета им. М.В. Аомоносова 119992, Россия, Москва,

Аенинские горы, 1-12 тел.: +7 4959394424 irbeme@mail.ru

\section{Contact:}

Igor Karyakin

Center of Field Studies Nizhegorodskaya str., 3-29

Nizhniy Novgorod Russia 603109 tel.: +7831433 3847 ikar_research@mail.ru

Ludmila Zinevich Koltzov Institute of Developmental Biology of Russian Academy of Sciences IDB RAS Vavilova str., 26 Moscow,

Russia, 119334 tel.: +7 49913533 22, fax: +7 4991358012 Izinevich@gmail.com

Darja Rozhkova Koltzov Institute of Developmental Biology of Russian Academy of Sciences IDB RAS

Vavilova str., 26

Moscow,

Russia, 119334

tel.: +79017439525

darroznature@

gmail.com

Elvira Nikolenko Sibecocenter, LLC P.O. Box 547 ,

Novosibirsk

Russia, 630090

tel.: +79231501279

elvira_nikolenko@mail.ru www.sibecocentr.ru www.rrrcn.ru

\section{Введение}

Бамобан (Falco cherrug) в России приблизился к той критической черте, за которой следует вымирание. В частности сокрашение численности этого вида в России уже по состоянию на 2010 г. составило 64,7 \% за 3 поколения (Мошкин, 2010) и вид продолжает сокрашаться (Карякин и sp., 2015), а обыкновенный балобан (F. ch. cherrug) потерял за 50 лет более 90 \% от численности и плошади гнездового ареала (только за период с 2003 по 2014 гг. потери в численности составили $74 \%$ при сокрашении плошахи ареала 82 \%: Карякин и мр., 2015). Последние крупные популяции балобана сохранились в Алтае-Саянском регионе, гле работы по их изучению веАутся членами Российской сети изучения и охраны пернатых хишников с 1999 г.

В базе данных Сети содержится информация о 387 гнездовых участках в российской части Аитае-Саянского региона (АнАреенков и Ар., 2017; RRRCN, 2017; GBIF, 2017), 29 \% которых были проверены в 2014 г. Многолетний мониторинг показаи пацение численности бамобана с 2003 г. на $27 \%$ в Республике Алтай, на 55 \% в Республике Хакасия, на 20 \% в Республике Тыва. Общее паление численности в российской части Аитае-Саянского региона составило 26 \% за период 2003-2014 гг. (Карякин и нр., 2014).

Основным негативным фактором, вызываюшим сокрашение численности бамобана, является браконьерский отлов птиц, преимушественно самок, мия нужА соколиной охоты (Карякин и Ар., 2015; Ковач и мр., 2014; Николенко и Ар., 2014). При этом браконьерами отлавливаются в первую очередь наиболее интересные мия сокольников птицы крупных размеров и редких фоорм окраски.

Алтайский бамобан - уникамьная тёмная морсра балобана, некогла относимая к самостоятельному виду аитайский сокол (Falco altaicus) (Сушкин, 1938), затем подвиду кречета (Falco rusticolus altaicus) (Аементьев, 1951), позже к алтайскому (Falco ch. altaicus), центраиьноазиатскому (F. ch. milvipes), мибо монгольскому ( $F$. ch. progressus) подвиду балобана (Аементьев, Шагларсурен, 1964; Степанян, 1990; Пфесрфер, 2009). В настояшее время эта форма сведена $\Delta о$ морфы (так называемый "аитайский" фенотип), возникаюшей в зоне интерградации трёх подвидов балобана на стыке Алтая, Тувы и Монголии (Карякин, 2011). Алтайский бамобан за посленние 20 лет фактически полностью

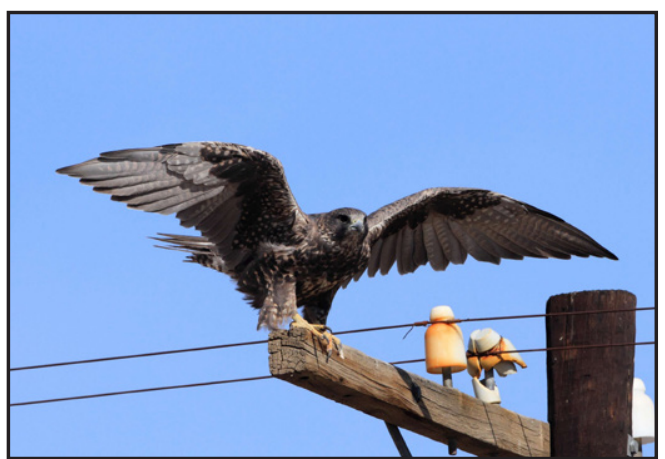

Балобан (Falco cherrug) "алтайского" фенотипа на зимовке в Северо-Запанном Китае. Фото Сюй Ажи.

Saker Falcon (Falco cherrug) of "Altaic" phenotype on wintering site in the Nort-Western China. Photo by Xu Jie.

\section{Introduction}

The overall population loss of the Saker Falcon (Falco cherrug) in Russian part of Altai-Sayan Ecoregion on 12 years period from 2003 to 2014 is $26 \%$ (Karyakin et al., 2014) mostly caused by poaching (Karyakin et al., 2015; Kovach et al., 2014; Nikolenko et al., 2014). A selective catching of birds of a bigsize and rare color morphs led the dark morph of the Saker to near extinction (Karyakin, 2011), which significantly depleted the gene pool of native populations of the species.

In the present project we studied the prospects of recovery of "Altaic" morph of the Saker in the wild by placing artificially bred "Altaic" nestlings to nests of native Sakers of other morphs.

Several falcon breeding centers in Russia are still have pure dark "Altaic" Sakers descended from few females caught in Altai in $90^{\text {th }}$. Haplotypes of these birds were sequenced beforehand to make sure that reintroduced falcons would feet the natural breeding population in the study area.

\section{Methods \\ Genetical analysis}

For genetical analysis we used samples of growing contour feathers with sheath (with some blood) from 10 artificially bred nestlings (reintroduced birds) and 24 native nestlings from broods of adoptive pairs. We also managed to take a sample from one adult female from the nest in Tuva Republic.

\section{Reintroduction}

Ten nestlings of a Saker descended from 4 pairs of captive-bred falcons of Altaic morph were bred in a breeding center "Vitasphera" in Moscow to the age of 20-27 days. In May 
Elena Shnayder

Sibecocenter, LLC

P.O. Box 547, Novosi-

birsk

630090, Russia

tel.: +79137956549

equ001@gmail.com

Eugenie Sarychev

"Vitasfera" LLC

Slobodino vil., Ramensiy

distr., Moscow region,

Russia

vitasfera@mail.ru

\section{Irina Beme}

Department of

Vertebrate Zool-

ogy, Faculty of Biology,

M.V.Lomonosov Mos-

cow State University

Leninskie Gory, 1-12,

Moscow, Russia 119992

tel.: +7 4959394424

irbeme@mail.ru

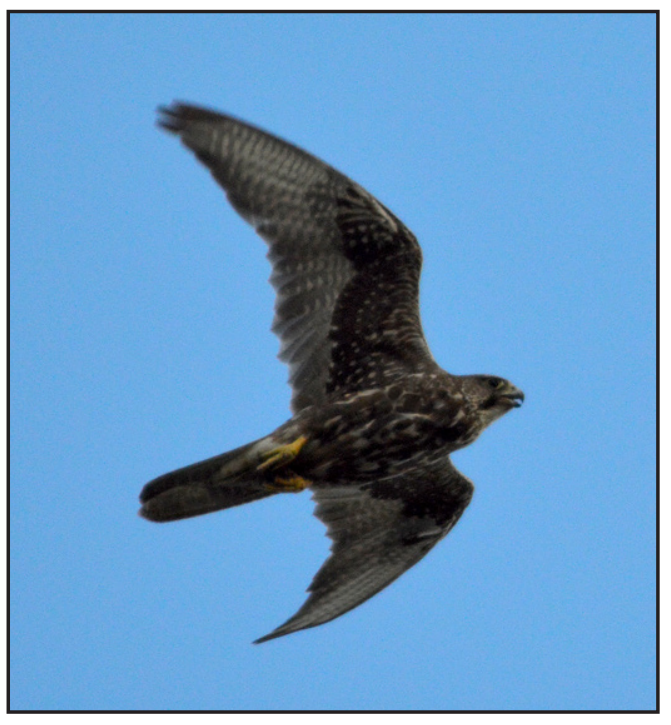

уничтожен в пределах Аитае-Саянского региона (Карякин и мр., 2015; Николенко, Карякин, 2016). Это привело к сушественному обеднению генофонда природных популяций вида, что, в свою очередь, несёт угрозу мия Аамьнейшего его выживания в природе. В свете этого перспективным Аля восстановления геносонда выглядит реинтродукция алтайского бамобана, вырашенного в питомниках. Но какими метоАами её осушествлять, каких птиц использовать Аля реинтродукции?

Цель настояшей работы - исследование перспектив реинтродукции алтайской морфы балобана путём подсаживания вырашенных в питомнике птенцов в естественные гнёзда балобанов Аругих морфр в Алтае-Саянском регионе.

$\triangle$ анная программа разработана и реамизована Российской сетью изучения и охраны пернатых хишников под эгидой МГУ при поцдержке ООО “Сибэкоцентр", The Altai Project/Earth Island Institute, А^таеСаянского отделения WWF, Фонда «Мир вокруг тебя" корпорации "Сибирское здоровье", Национального парка "Саймюгемский", заповедника "Убсунурская котловина". Птенцы алтайских балобанов были вырашены в ООО «Питомник реАКИХ ВИАОВ ПтИЦ ВИТАСФЕРА" (Г. Москва) и предоставлены мия целей проекта на безвозмездной основе. В части прослеживания соколов с помошью трекеров, проект поциержаяи Польская компания "Ecotone" (производитель трекеров, предоставившая их безвозмездно) и Международная ассоциация сокольников (IAF) (оплатила прослеживание соколов).

В проектах по реинтродукции редких видов в настоящее время особое внимание уделяется генетическому разнообразию и
Бамобан "аитайского" фенотипа на гнездовом участке в Туве. Фото И. Карякина.

Saker Falcon of "Altaic" phenotype on breeding territory in the Tyva Republic. Photo by I. Karyakin.

of 2017 the nestlings were brought to AltaiSayan region by plane and placed to nests of a wild Sakers before 5 of July. All breeding territories used for reintroduction were previously known to be used by Sakers of Altaic phenotype before the Altaic morph collapsed in numbers (Karyakin, 2011).

Three nestlings were introduced to a nest with 4 native nestlings of 15-20 days old located in a Saylugem National park in Altai Republic. Due to local shortage of prey in 2017 in this area we arranged a supplemental feeding for nestlings by delivering domestic hamsters, rats and 1-day old chickens (all sacrificed beforehand and stored in a freezer) to the nest daily until all nestlings are fledged. A real-time 24-hour video translation and recording was organized.

The other 7 nestlings were introduced to 5 nests of wild Sakers that breed on artificial breeding platforms in Tyva Republic (Karyakin, Nikolenko, 2011; Nikolenko et al., 2016) by 1-2 extra nestlings per nest that already have 3-5 native nestlings. First arrivals of adult Sakers to the nests were recorded on video by camera-traps.

\section{Tracking of reintroduced birds after they fledged}

Three nestlings (one non-native and two native) from the nest in Altai Republic were tagged with GPS/GSM backpack trackers produced by Ecotone (Poland). Trackers were attached by $6 \mathrm{~mm}$ width Teflon harness (Karyakin, 2004). Monitoring was proceeded via data-portal of Ecotone company. Telemetry data was processed in ArcView 3x by means of AnimalMovement SA v. 2.04 module (Hooge, Eichenlaub, 1997; Hooge et al., 2001).

\section{Results}

Genetic correspondence of the introduced nestlings to the natural population in the project location

Preliminary results of the mitochondrial Dloop fragments from 414 to 1417 bps (1004 bp) analysis for the introduced and natural birds in the Altai-Sayan region and for control samples are presented at figure 1 . The native as well as introduced nestlings had D-loop fragment sequences of two distinct groups. The determined haplogroups are in correspondence 
происхождению животных, вводимых в восстанавливаемые популяции. Так, генетическая паспортизация с использованием микросатемитных маркеров и изучение вариабельности генотипа у реинтродуцируемых сапсанов (Falco peregrinus) в Польше показали, что 308 выпушенных в природу птиц характеризоваиись $\Delta$ овольно низкой генетической изменчивостью - у них было обнаружено от Авух Ао девяти амелей мля локуса, но средняя наблюдаемая гетерозиготность составила 0,34, что крайне мамо мия нативных популяций сапсана (Nowak, Sielicki, 2017). Соответственно, при реинтродукции птиц со столь низкой вариабельностью генотипов, сохраняется угроза устойчивому выживанию сформированных популяций в дальнейшем, при каких-либо изменениях в среде обитания.

Особую важность представляет использование мия реинтродукции птиц из геносонда, соответствуюшего популяциям, населяюшим или ранее населявшим данную территорию. А в случае с восстановлением угасаюших популяций желательно выпускать птиц, принамежаших к одним и тем же гаплогруппам, чтобы избежать внесения искусственным путём чужеродных форм. Эта позиция закреплена в Европейском законодательстве, а в случае с крупными соколами является особенно актуальной, так как имеется опасность выпуска в природу чужеродных подвидов, а также межвидовых гибридов из группы Hierofalco (например, гибридов кречета Falco rusticolus и бамобана, или вообше чужыых мия России маггара $F$. jugger и ланнера $F$. biarmicus), способных размножаться с нативными соколами.

В нескольких питомниках России сохранились настояшие тёмные "аитайские" бамобаны, происходяшие от нескольких самок, отловленных на Алтае в 90-х гг. по разрешениям Госкомэкологии. Уникальные генетические маркеры алтайской морфы остаются невыявленными, однако фенотип является устойчивым и наследуется при скрешивании тёмной морсы с Аругими морсрами восточных подвиАОв балобана с образованием различных фенотипов, вкАючая типичный алтайский.

Таким образом, реинтродукция алтайской морсы бамобана в её природные местообитания может повысить как численность исчезаюшего вида в природе, так и генетическое разнообразие природных популяций и в перспективе - восстановить прежнюю популяционно-генетическую with the previously determined haplogroups $A$ (eastern Sakers and Gyrfalcons) and B (western Sakers) described by Nittinger et al. (2007) on the base of the shorter D-loop fragments (see Fig. 2 and Table 1). In particular cases the introduced nestlings and natural birds had the same D-loop haplotypes (Table 2).

\section{Inheritance of "Altaic" phenotype in Saker}

Video recording on the nest in Altai Republic revealed that one non-native nestling has a "siberian" pigmentation of feathers (previously described as a Siberian subspecies of the Saker $F$. ch. saceroides) that is also present in a native population in Altai-Sayan region. The other non-native nestling from the same nest has a typical pigmentation of "Altaic" subspecies. The third introduced nestling from this nest was killed by an Eagle Owl before it got its feathers grown, thus we know nothing about its coloration. All nestlings reintroduced in Tuva Republic has a typical pigmentation of "Altaic" subspecies.

Most of the native nestlings under study have "Siberian" and "Mongolian" phenotypes ( $F$. ch. progressus). However, in one nest where both parents have "Siberian" phenotype among 5 siblings we found one nestling with "Altaic" phenotype. Unfortunately, that very chick died by an unknown reason being already fully fledged.

\section{Introducing of nestling of a Saker to na- tive nests and supplementary feeding}

We observed no cases of aggression between native and non-native nestlings in nest. Responce among non-native nestlings on adult bird appearance was completely the same as among native nestlings. In all cases adult females returned on the nest in one hour after disturbance caused by ornithologists who added extra nestlings. Females showed no aggression towards new nestlings and fed them like their own, despite differences in coloration of nestlings and in some cases age.

Observations from camera on the nest in Altai Republic showed that nestlings accepted each type of supplementary forage (Djungarian hamsters, European hamsters, laboratory Wistar rats, Brown rats, 1-day old chickens) and at the age of 30 days began to tear prey and eat by themselves. Adult female from the nest readily fed nestlings with chickens and hamsters but avoided white Wistar rats. At the first appearance of a white rat on a nest female kept away for few hours but later got used to it. On the other hand, brown rats female preferred to consume by herself away from the nest. 
структуру вила в Алтае-Саянском регионе. мя чего одной из киючевых задач нашего проекта было определение гаплотипов бамобанов, вырашенных в питомнике, мяя обеспечения их реинтродукции в места гнездования нативных птиц с близкими и/ или такими же гаплотипами.

\section{Методика}

В настояшее время сушествует несколько возможныХ пОАХОАОв К восстановлению утраченных или угасаюших популяций соколов: во-первых, вырашивание птенцов в искусственных гнёздах (хеках) дмя формирования нужного стереотипа гнездования, во-вторых - подсаживание птенцов, вывеАенных в питомнике, в естественные гнёзда мия выкармливания приёмными родитемями. Оба метода применялись успешно мля восстановления популяций сапсана ( $F$. peregrinus), однако при втором способе эсфективность выпусков была более высокой (Burnham, Cade, 2003).

Аля бамобана известны попытки реинтродукции молодых птиц в странах Евросоюза, например в Чехии (Horak, 1987) и Болгарии (Ragyov et al., 2012). Успешность проекта в Болгарии на начальном этапе оказалась низкой из-за гибели птиц за пределами натальной области (Saker Falcon..., 2012), хотя перед выпуском были реализованы мероприятия по восстановлению популяций сусликов и реконструкции АЭП на безопасные м^я соколов в зоне их выпуска, а все высаживаемые в хеки птенцы выживами $А$ вылета (Ragyov et al., 2010; 2012). Мечение спутниковыми передатчиками птиц старше года, отловленных ранее в природе и реабилитированных, также показало низкую их выживаемость после выпусков (Muller, 2013). Всё это указывает на необходимость отработки методик реинтродукции и повышения их результативности. А лучшим способом не Аать виду

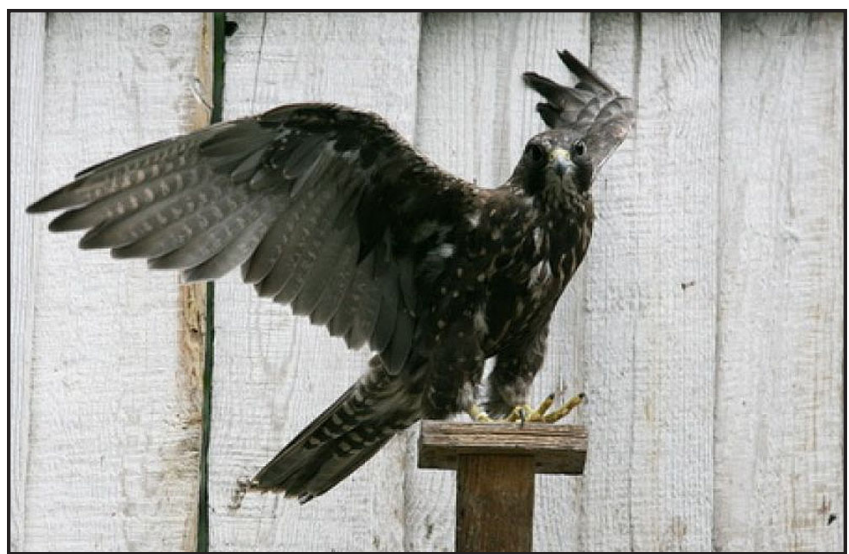

\section{Leaving the nest}

Nestlings from the nest in Altai Republic that survived attack of an Eagle Owl (Bubo bubo) left the nest at the age of 43-45 days and kept near returning to the nest from time to time. Lately, one more nestling from this brood was killed by an Eagle Owl.

Nest checking in Tuva showed that all nonnative nestlings successfully left the nests, but three native nestlings died. Two nestlings died in a nest built on an open platform located on a concrete pole in an open steppe landscape away from shelterbelts. The brood consisted of 4 native and 2 introduced nestlings -6 in total. One nestling with growing feathers felt down from the nest and died from starvation, another one - fully fledged and flying - was killed by a bigger raptor near the nest. One more native nestling from a brood of 7 nestlings ( 5 native and 2 introduced) died in the nest located on a platform on a poplar tree. The reason of death is unknown. It could be either infection or poisoning since the nestling was already fledged and ready to flight and it corpse had no sign of starvation. That was the native nestling with "Altaic" phenotype.

As a result, from the total 34 nestlings (24 native and 10 non-native) 30 nestlings fledged and left the nest, 28 of them survived the post-fledgling dependence period before birds abandoned the nestling area. The total losses are $17.65 \%$ of nestlings, survival rate $-82.35 \%$ (table 3 ).

\section{Post-fledgling period and migration}

On June 17 during the nestling period three nestlings from the nest in Altai Republic were tagged with GPS/GSM trackers. In a week after tagging all nestlings made their first flight and then kept in the vicinity of the nest till the middle of July. To the greatest disappointment, only one falcon out of three stays in touch until now - a native female named Uchsyn that means "Let it fly" in Altai language. We lost one native male due to Eagle Owl attack on July 16, and lost contact with introduced male due to tracker breakdown on July 1 .

After fledglings left the nest and until the incident with an Eagle Owl they stay in the nesting area no more than $4 \mathrm{~km}$ from the nest. In her movements female covered $8.3 \mathrm{~km}^{2}$, male covered $5.3 \mathrm{~km}^{2}$ (fig. 3).

Бамобан "аитайского" фенотипа в питомнике Фото О. БогАанова.

Saker Falcon of "Altaic" phenotype in breeding center. Photo by O. Bogdanov. 
исчезнуть, видится всё же реализация мероприятий по его восстановлению $\Delta о$ того, как он выпал из гнездовой фауны того или иного региона, наряну с нейтрамизацией основных негативных фракторов (браконьерство, гибель на ЛЭП), к чему мы собственно и стремимся в Алтае-Саянском регионе.

В нашем проекте был выбран метод, при котором птенцы, выведенные в питомнике, подсаживаются в естественные гнёзда в природе, к родному выводку "приёмных" родителей.

\section{Методика генетического анамиза}

Аля генетического анализа были использованы трубки растуших перьев с кровью от 10 птенцов из питомника и 16 их собратьев из приёмных гнёзд, также улалось взять материал у одной взрослой самки на гнезде в Туве. Аия сравнения в анализ включияи также образцы $\Delta \mathrm{HK}$ из кинных перьев кречета, нативного обыкновенного балобана из Крыма, а также образцы от птенцов из Запацной Монголии (7), Тувы (4) и Хакасии (2), гле в Аальнейшем также планируются мероприятия по восстановлению гнездовых группировок бамобанов амтайского фенотипа.

$\Delta$ НК экстрагировами с помошью коммерческого набора реактивов Diatome DNA Prep 100 (Россия) согласно протоколу производителя.

Полимеразную цепную реакцию проводили с помошью набоpa ScreenMix-HS (Евроген, Россия) и амплисрикатора VeritiFast (Applied Biosystems, США) с использованием разработанной нами библиотеки специсрических праймеров мия фррагмента контрольного региона (D-петли) митохондриального генома (прямые 5'-3': ACTAAACCCATGCCCTGTAT, G C C C T T C T C C G A G C C A T C T G, CGGTTTGCGTATTTGGAGTCA; обратные 5'-3': GAACCAACCGCCCCAAAAAG, GGGTA GGGGGTTTTA A GTTTTTGT, TCGGGCGGTTTAGGTTTATTGG). Секвенирование по Сэнгеру проводили с помошью реактивов BigDye 3.1 на приборе ABI 3500 (Applied Biosystems, США). Подбор праймеров и обработку результатов секвенирования проводили с помошью программного пакета Lasergene (DNASTAR, США). Поиск полиморфных сайтов и построение Аендрограмм осушествляли с помошью программного пакета Mega 7 (MEGA, США).
After July 16 , when the male was predated by an Eagle Owl, Uchsyn the female left the nesting area and significantly increased the area of her movements from $8 \mathrm{~km}^{2}$ to $8715 \mathrm{~km}^{2}$. The length of her route makes more than $1,500 \mathrm{~km}$ in one month.

In total, the area covered by Uchsyn from the moment she left the nest and until the beginning of her migration to winter sites makes 47,949.2 $\mathrm{km}^{2}$; $95 \%$ Kernel for the nesting area - $777.77 \mathrm{~km}^{2}$, away from it 704.92 km² (fig. 5). In Uchsyn's movements we allocated two major territories separated from each other by $75 \mathrm{~km}$ that she preferred to stay in before starting active migration.

A full track of Uchsyn from July 1 to December 15 of 2017 is shown on fig. 6. During this period we got 2,408 points from her tracker. The mean number is $401.33 \pm 82.20$ locations per month (minimum - 311 locations in November, maximum - 513 locations in July). The length of her route is $12,127.9 \mathrm{~km}$; average per month is $2,021.31 \pm 751.36 \mathrm{~km}$ : from $1,182.5 \mathrm{~km}$ in July to 2,986.1 km in September (table 4).

The distance from the nesting area to the most remote point of Uchsyn's track is $1,452 \mathrm{~km}$, azimuth $-149^{\circ}$; this point Uchsyn reached on a 104 day after she left her nesting area and on a 71 day after she started active migration. The distance between the nesting area and major wintering sites in mountains of Mongolian Altai is $738 \mathrm{~km}$, azimuth $-125^{\circ}$. The area covered in her winter movements including visiting China is 283,485.34 km²; $95 \%$ Kernel $-10,616.16 \mathrm{~km}^{2}$; the area covered in movements on her major wintering site in Mongolian Altai is $23,406.71 \mathrm{~km}^{2}, 95 \%$ Kernel - 642,82 km² (fig. 7).

\section{Conclusions}

1. Introducing Saker's nestlings to the native broods is a good method for their integration into the wild. In the situation of abundance of prey broods of 6 nestlings could survive without making harm to the smallest nestlings; in the case of prey storage supplementary feeding could fix the problem.

2. The area for project implementation must be remote from human settlements and other public places to prevent disturbing and to attract no poachers.

3 . The nest of adoptive pair should be selected well. Preferably it should be remote from nests of other big raptors, especially from Eagle Owl's nests.

4. If it is not possible to select a nest located distantly form nests of other raptors 


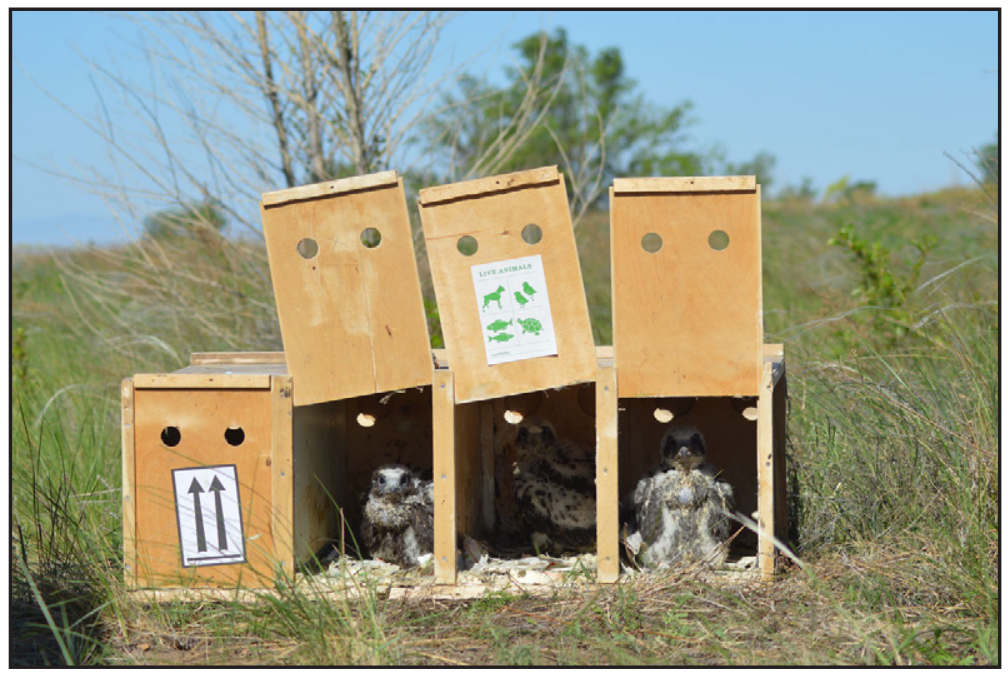

Птенцы балобана "ачтайского" фенотипа перед выпуском в природу.

Фото И. Карякина.

Saker Falcon nestlings of "Altaic" phenotype before release into wild. Photo by I. Karyakin.

Птенец бамобана "аитайского" фенотипа, подсаженный в естественное гнездо в июне (сиева) и он же после вылета из гнезда со СвОИми СвОАНЫми собратьями (справа). Фото И. Карякина и А. Куксина

Nestling of a Saker of "Altaic" phenotype in adoptive family of wild Sakers (at the left) and the same nestling after fledgling with other nestlings (at the right). Photos by I. Karyakin and A. Kuksin.
Определение пола птенцов балобана проводили по размеру интронов гена CHD1 в половых хромосомах (Fridolfsson, Ellegren, 1999).

\section{Методика выпуска птенцов}

$\triangle$ есять птенцов балобана от четырёх пар алтайской морсы, были вырашены в питомнике "Витассрера" $А$ возраста 20-27 Аней при естественном вскармиивании роАителями. В мае 2017 г. эти птенцы были Аоставлены самолётом в Алтае-Саянский регион и в течение недели высажены в естественные гнёзда.

Три птенца были подсажкены в жилое гнездо бамобанов в Республике Аитай, где в естественном выводке было четыре птенца возрастом 15-20 дней. В текушем году на территории, гле было расположено это гнездо, наблюдаяась глубокая депрессия основных объектов питания балобана - мииннохвостого сусиика и монгольской пишухи. Поэтому после высацки птенцов и $А$ их окончательного вылета тут велась подкормка птиц суточными цыплятами, хомяками и крысами, также на гнезде было организовано круглосуточное видеонаблюдение.

Остальные 7 птенцов были высажены по 1-2 в 5 жилых гнёзд балобанов на плат- then supplemental feeding of other raptor's brood could solve the issue of predating young falcons by a bigger raptor. It is also possible to scare the Eagle Owl away from the Salker's nest at night time by using flashing lights with a motion detector. This system could protect nestlings before they leave a nest.

5 . For big broods (6-7 nestlings) it is necessary to arrange a big-size nesting platform with diameter not less than $1.2 \mathrm{~m}$ with skirting to prevent nestlings from falling from a nest.

6. A temporal video-translation from the nest for several hours after adding extra nestlings could be very helpful in a case when urgent actions are needed.

7. Obtained results are consistent with our previous assumption (Karyakin, 2011), that "Altaic" morph of Saker occurs in the intergradation area of nominative subspecies of Saker ( $F$. ch. cherrug) related to the western haplogroup and eastern subspecies of Saker ( $F$. ch. milvipes and $F$. ch. progressus) related to the eastern haplogroup that also includes Gyrfalcons. Therefore, Sakers of "Altaic" morph could be splitted by female line into two haplogroups both are presented in Altai-Sayan region. In other regions where only one mitochondrial haplogroup occurs (Western and Central Kazakhstan, Central Mongolia, Tibet) "Altaic" morph is not presented.

8. Nowadays, when "Altaic" morph is nearly extinct from nature, its population recovery in Altai-Sayan region by means of reintroduction captive-breeding birds is a very actual issue from the point of preservation of biodiversity. However, since in breeding pairs of phenotypically pure "Altaic" Sakers offspring could have phenotype of anther morphs more attention must be paid to studying of mechanism of origin of dark Altai Sakers in the intergradation zone of three subspecies of Saker in Altai-Sayan region using molecular-genetic methods.

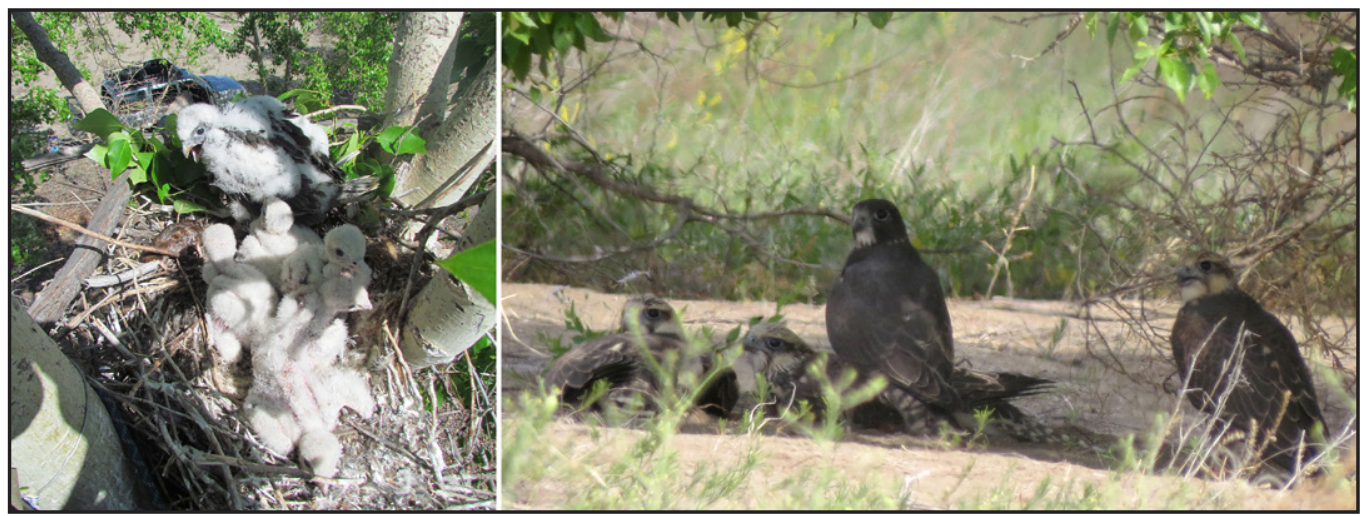




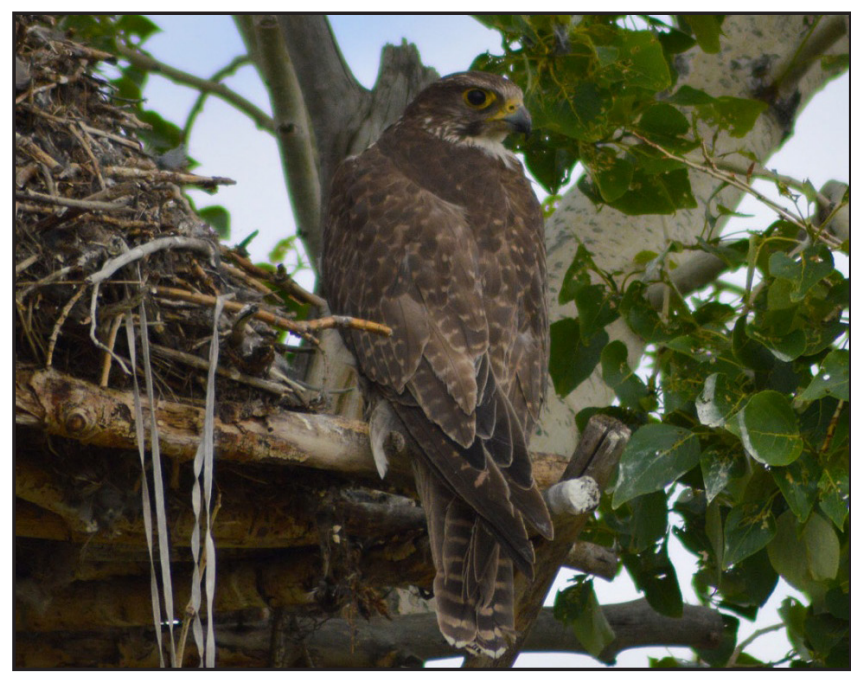

формах на экспериментаиьной площалке в Туве, гле кормовая ситуация была стабильной, и в естественных выводках было от 3 Ао 5 птенцов. На Аанной территории с 2006 г. реамизуется проект по установке гнездовых платсрорм, нацеленный на увеличение численности сокола-балобана (Карякин, Николенко, 2011). За 10 мет реализации проекта были достигнуты значительные результаты: на территории, где балобан полностью исчез на гнездовании ешё до 2003 г., через 8 лет проекта, в 2014 г., 13 участков было занято балобанами, на 8 из них наблюдалось размножение (Николенко и др., 2016).

Все птенцы были высажены в гнёзда на территориях, на которых ранее наблюдамось гнездование балобанов амтайского фенотипа (Карякин, 2011). Работы по высахке птенцов были завершены к 5 июня.

Аля отслеживания поведения птиц на всех естественных гнёздах балобанов в первые часы после посадки птенцов, на них были установлены вилеорегистраторы. Через 3-4 недели (29 июня - 2 июля) была проведена проверка гнёзд мля определения успеха вскармливания и вылета как подсаженных, так и природных птенцов.

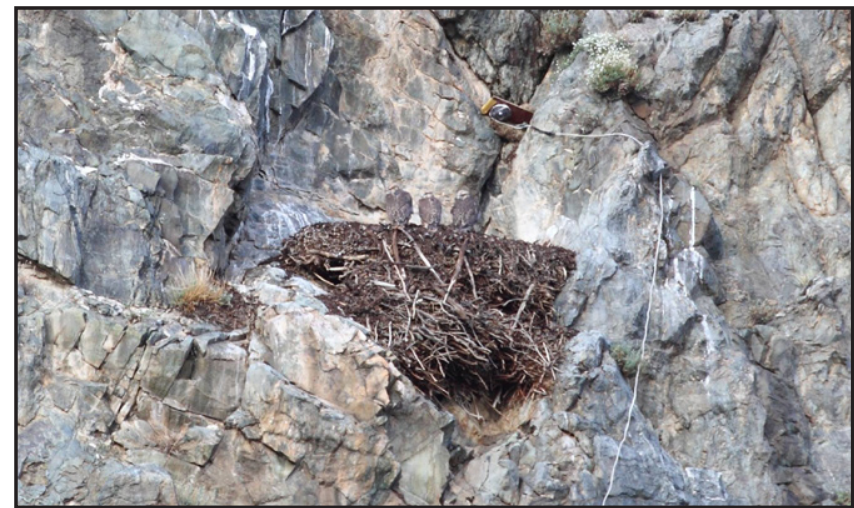

Самка бамобана "сибирского" фенотипа (saceroides). К таким соколам в основном и были подсажены птенцы из питомника. Фото И. Карякина.

Female Saker of the "Siberian" phenotype (saceroides). In our project, adult birds from adoptive pairs were mostly of this phenotype. Photo I. Karyakin.

Bсе птенцы, вырашенные в питомнике, были помечены несъёмными алюминиевыми кольцами с аббревиатурой RUVS. Перед подсадкой в гнёзда они наряду с нативными птенцами были помечены пластиковыми кольцами по схеме Центра кольцевания Российской сети изучения и охраны пернатых хишников мия Аитае-Саянского региона (Образцы..., 2017). Нативные птенцы также были помечены разъёмными амюминиевыми кольцами Российского центра кольцевания.

\section{Методика отслеживания перемеше- ний птенцов после вылета}

Незадолго Ао вылета 17 июня 2017 г. на трёх птенцов (одного "питомниковского" и 2-х нативных - самца и самку) в алтайском гнезде были надеты GPS/GSM трекеры Польской компании Ecotone. Из нативных птиц трекерами были помечены два самых младших птенца, чтобы понять успешность их выживания в дикой природе в мальнейшем. Трекерь были надеты в виде рюкзачков (Карякин, 2004) с использованием упряжи, сшитой из теслоновой ленты, диаметром 6 мм. Масса передатчиков была менее $3 \%$ от массы тела птенцов, т.е. меньше оптимального значения, рекомендуемого Аля телеметрических исследований птиц (Caccamise, Hedin, 1985; Kenward, 2001).

Слежение за птицами осушествлялось через портаи данных компании Ecotone. Трекеры были запрограммированы на отправку 18 локаций в световой день с 4:00 Ао 21:00 местного времени. Результать телеметрии обрабатываиись в ArcView 3x с помошью модуля AnimalMovement SA v. 2.04. Аия области летних и зимних перемешений орлов рассчитывамись минимамь-

Гнездо балобана с камерой видеонаблюдения нах ним. Фото Е. Шнайдер.

Nest of the Saker Falcon with video camera above the nest. Photo by E. Shnayder. 


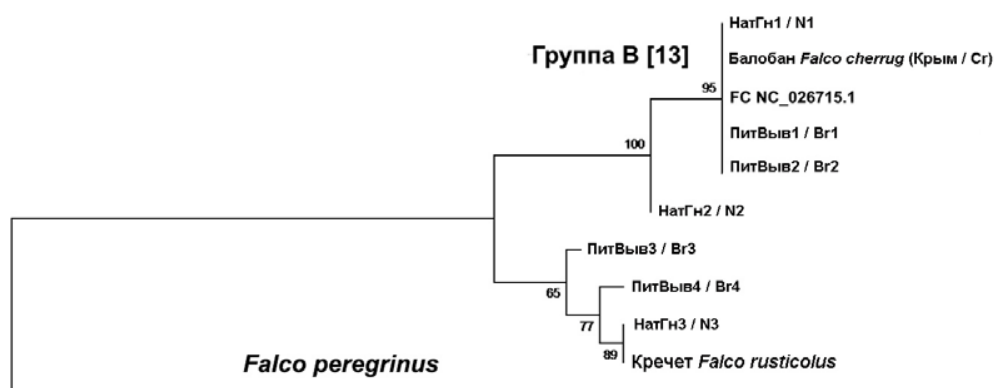

Группа A [13]

0.0050

Рис. 1. Аендрограмма гаплотипов фрагмента 1004 bp D-петли, построенная методом максимального правдоподобия. Модель Хасегава-Кишино-Яно, гаммараспределение (5 категорий), бутстреп 1000, циина ветвей отражает число замен на сайте Условные обозначения: ПитВыв 1-4 - образцы $\Delta$ НК птенцов

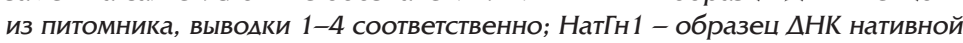
взрослой самки (Тува); НатГн2-3 - образцы НК нативных птенцов из АитаеСаянского региона (Монголия и Хакасия соответственно); Балобан Крым образец $\triangle H К$ из минного пера нативной птицы крымского изолята запацной популяции; Кречет - образец $\triangle H К$ из Аинного пера взрослой самки кречета из питомника. FC NC_026715.1 и FP JX029991.1 - анамизируемые фррагменты последовательностей мт-геномов балобана и сапсана из GenBank с соответствующими номерами.

Fig. 1. Molecular Phylogenetic analysis of 1004-bp D-loop fragment obtained via Maximum Likelihood method. Hasegawa-Kishino-Yano model with a discrete 5 categories Gamma distribution, bootstrap 1000, branch lengths measured in the number of substitutions per site. Legend: $\mathrm{Br} 1-4$ - samples from nestlings from the breeding center (4 different broods), N1 - DNA sample from the wounded adult Saker female (Tyva Republic), N2-3 - samples from nestlings from 2 native nests in the Altai-Sayan region (Mongolia and Khakassia respectively). Falco cherrug $\mathrm{Cr}$ - the DNA sample from the molted feather of the natural western Saker nesting in the Crimean isolate, Falco rusticolus - the DNA sample from the molted feather of the Gyrfalcon from the breeding center. FC NC_026715.1 and FP JX029991.1 - relevant fragments of the Saker and the Peregrine mitochondrial genomes sequences with the particular GenBank numbers.

ный конвексный полигон (МСР) и зона с максимальной плотностью распределения 95 \% локаций (Kernel, 95 \%) (Hooge, Eichenlaub, 1997; Hooge et al., 2001).

Табл. 1. Распределение гаплогрупп D-петли митохондриального генома среди выпушеных птенцов балобана (Falco cherrug) "аитайского" фенотипа и птенцов из природных выводков.

Table 1. Mitochondrial D-loop haplogroups distribution in the reintroduced "Altaic" and native Saker Falcon (Falco cherrug) nestlings.

\begin{tabular}{|c|c|c|c|}
\hline $\begin{array}{l}\text { Место } \\
\text { происхожиения } \\
\text { балобанов (Falco } \\
\text { cherrug) } \\
\text { Place of origin of the } \\
\text { Saker Falcon (Falco } \\
\text { cherrug) }\end{array}$ & $\begin{array}{l}\text { Группа A - } \\
\text { восточные } \\
\text { балобаны и } \\
\text { кречеты } \\
\text { Group A } \\
\text { - Eastern } \\
\text { Sakers and } \\
\text { Gyrfalcons }\end{array}$ & $\begin{array}{l}\text { Группа B - } \\
\text { запалные } \\
\text { балобаны } \\
\text { Group B - } \\
\text { Western } \\
\text { Saker Falcons }\end{array}$ & $\begin{array}{l}\text { Всего } \\
\text { вывоцков } \\
\text { All broods }\end{array}$ \\
\hline $\begin{array}{l}\text { Природные птицы } \\
\text { из Алтае-Саянского } \\
\text { региона } \\
\text { Natural birds from the } \\
\text { Altai-Sayan region }\end{array}$ & 4 & 6 & 10 \\
\hline $\begin{array}{l}\text { Питомниковские } \\
\text { птенцы «аитайского } \\
\text { фенотипа" } \\
\text { Nursery nestlings of the } \\
\text { “Altaic phenotype” }\end{array}$ & 2 & 2 & 4 \\
\hline
\end{tabular}

\section{Результаты}

Генетическое соответствие подсаживаемых птенцов нативным птицам в местах реамизации проекта

Предварительные результаты анаииза последовательностей контрольного региона (D-петли) митохондриамьного генома от 414 ло 1417 bр (1004ьр) мия подсаженных и нативных птиц в Алтае-Саянском регионе, а также образцов сравнения преАставлены на рисунке 1.

Как нативные, так и подсаженные птенцы имеют гаплотипы D-петли, принацежашие к Авум достоверно разделяюшимся гаплогруппам. Сравнение последовательностей наших соколов с последовательностями гаплотипов D-петли, полученных Ф. Ниттингер с соавторами (Nittinger et al., 2007) по более коротким фрагментам, показа^о, что выделенные нами гаплогруппы соответствуют описанным ранее гаплогруппам А (восточный бамобан и кречет) и В (запанный бамобан) (см. рис. 2 и табл. 1). B отдельных случаях гаплотипы D-петли у подсаженных птенцов полностью соответствовами таковым у нативных птиц (табл. 2).

\section{Наследование фенотипа амтайского балобана}

$\Delta$ есять выведенных в неволе птенцов происходики от четырёх пар фенотипически чистых "аитайских" бамобанов, многократно размножавшихся в питомнике. При высаживании в возрасте 21-30 дней детаиьно определить окраску птенцов было невозможно. ОАнако постоянное видеонаблюдение на одном из гнёзд, куда были высажены три птенца, у одного из них при окончательном раскрытии пера выявило окраску, типичную мия сибирского “ренотипа" (ранее описывался как сибирский подвид F. ch. saceroides), также встречаюшейся в Алтае-Саянском регионе. Аругой подсаженный в это гнезАо птенец после оперения имел типичный фенотип “алтайского" балобана. Все птенцы, высаженные в тувинские гнёзда, имели типичный фенотип «амтайского» бамобана.

Большинство нативных птенцов, в гнёзАа которых подсаживались птенцы из питомника, имели фенотипы "сибирского" и "монгольского" (F. ch. progressus) балобанов. ОАнако в одном гнезде, гле обе взрослые птицы имели фенотип "сибирского" балобана, в выводке из 5 птенцов, один оказался с фенотипом "аитайского" бамобана. К сожамению, именно этот птенец погиб по неизвестной причине, уже будучи полностью оперённым (см. ниже). 
Рис. 2. Сеть из 87 митохондриальных гаплотипов четырёх видов Hierofalсо из: Nittinger et al., 2007. Кажжый круг преАставляет собой один гаплотип, его размер пропорционален частоте встреч этого гаплотипа в изученной выборке. Маленькие чёрные точки обозначают недостаюшие гаплотипы, а соединительные Аинии преАставляют собой шаги с одной мутацией. Заштрихованная миния указывает на разАеление межАу двумя основными группами гапиотипов (А и В).

Fig. 2. Network of the 87 mitochondrial haplotypes of the four Hierofalco species from: Nittinger et al., 2007. Each circle represents one haplotype, its size is proportional to the frequency of that haplotype. Small black dots stand for missing haplotypes and connecting lines represent singlemutation steps. The hatched line indicates the split between the two major haplotype groups ( $A$ and $B$ ).

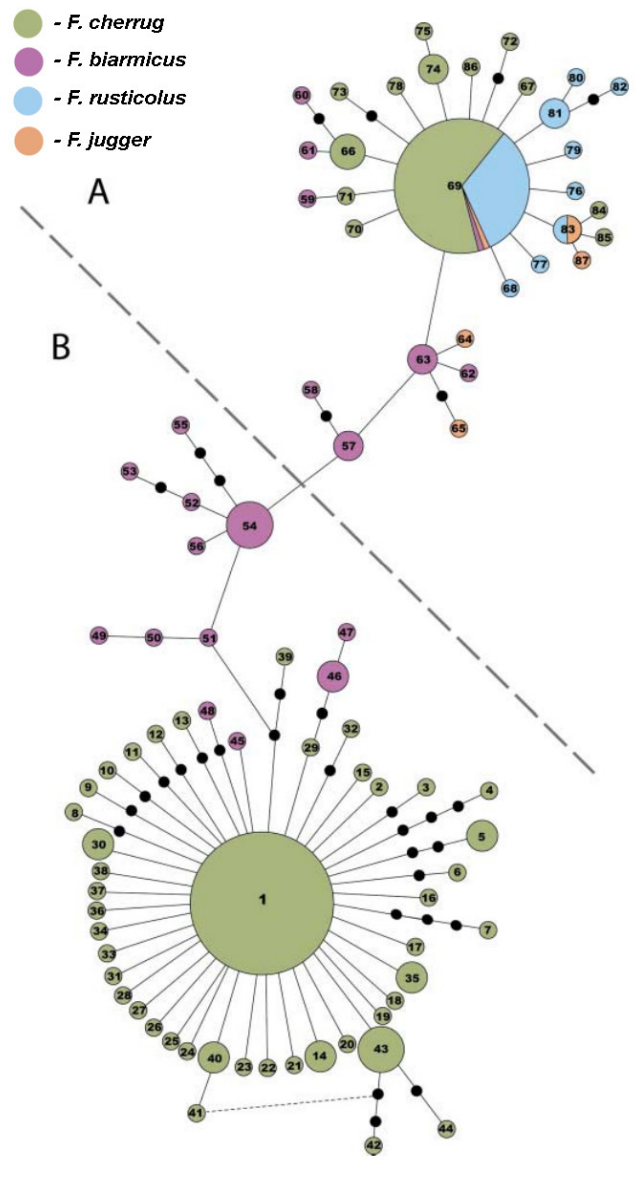

Подсаживание птенцов балобана в естественные гнёзда и организация подкормки

При высаживании птенцов, вырашенных в питомнике, в естественные гнёзда балобана, не наблюдалось ни одного случая агрессии птенцов Аруг к Аругу. Реакция подсаженных птенцов на появление взрослых птиц в пределах видимости была полностью аналогична реакции диких птенцов. Взрослые самки во всех случаях возврашаиись на гнездо в течение первого часа видеонаблюдения и также не проявляли никакой агрессии к подсаженным птенцам и сразу приступали к кормлению - как родных птенцов, так и подсаженных, несмотря на разницу в окраске, а иногда и в возрасте. Самцы также не проявляли агрессии к птенцам, хотя на одном из гнёзд самец атаковал установленный на край гнезда видеорегистратор (Стартоваи первый проект..., 2017).

Аолговременное круглосуточное наблюАение, организованное вместе с регулярной подкормкой на гнезде в Республике Алтай, также не выявило сушественной разницы в поведении птенцов, вырашенных в питомнике, и диких птенцов, а также в реакциях взрослых птиц на них.

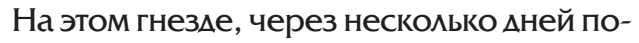
сле подсадки птенцов, один из подсаженных птенцов и один из Аиких были Аобыты филином (Bubo bubo), гнездо которого было обнаружено в 500 м от исследуемого гнезда бамобана. Это случимось в Ани АожАиивой погоды. По-видимому, из-за плохой кормовой ситуации, в гнезде фимина один птенец погиб - рядом с гнездом были найдены его останки. Также на этом участке в связи с негативной кормовой ситуацией погибли вывоАКи мохноногого курганника (Buteo hemilasius) и степного орла (Aquila nipalensis). В то же время при организованной регулярной подкормке оставшиеся 5 птенцов балобана (2 подсаженных и 3 родных) благополучно доросли $\Delta$ в вылета.

Табл. 2. Описание гаплотипов D-петли митохондриамьного генома балобанов: молекулярно-генетическое сопровождение выпуска птенцов в природу.

Table 2. Mitochondrial D-loop haplotypes definition of the Saker Falcon: the molecular support for the reintroduction project.

\begin{tabular}{|c|c|c|c|c|c|c|c|}
\hline \multirow{4}{*}{$\begin{array}{l}\text { Гаплотип по } \\
\text { D-петле и } \\
\text { гаплогруппа } \\
\text { (Nittinger et } \\
\text { al., 2007) } \\
\text { D-loop hap- } \\
\text { lotype and } \\
\text { haplogroup } \\
\text { (Nittinger et } \\
\text { al., 2007) }\end{array}$} & \multicolumn{5}{|c|}{$\begin{array}{l}\text { Aитае-Саянский регион } \\
\text { Altai-Sayan region }\end{array}$} & \multicolumn{2}{|c|}{$\begin{array}{l}\text { Контроль (Аругие регионы) } \\
\text { Control (other regions) }\end{array}$} \\
\hline & \multicolumn{6}{|c|}{ Балобан (Falco cherrug) } & \multirow[t]{2}{*}{$\begin{array}{l}\text { Кречет } \\
\text { (Falco rusticolus) }\end{array}$} \\
\hline & Выводки из & Выводки из & природы / В & roods from $n$ & ature & & \\
\hline & $\begin{array}{l}\text { OOO “Вита- } \\
\text { сфера" } \\
\text { Broods from } \\
\text { nursery "Vita- } \\
\text { sfera" LLC }\end{array}$ & $\begin{array}{l}\text { Хакасия } \\
\text { Republic of } \\
\text { Khakassia }\end{array}$ & $\begin{array}{l}\text { Tyвa } \\
\text { Republic of } \\
\text { Tyva }\end{array}$ & $\begin{array}{l}\text { Алтай } \\
\text { Republic of } \\
\text { Altai }\end{array}$ & $\begin{array}{l}\text { Запацная } \\
\text { Монголия } \\
\text { Western } \\
\text { Mongolia }\end{array}$ & $\begin{array}{l}\text { Крым } \\
\text { Crimean } \\
\text { Peninsula }\end{array}$ & $\begin{array}{l}\text { Питомник } \\
\text { \«Аитай } \\
\text { Фалькон" } \\
\text { Nursery “Altai- } \\
\text { Falcon" }\end{array}$ \\
\hline H-69 (A) & 1 & 3 & 1 & & & & 1 \\
\hline $\mathrm{H}-74(\mathrm{~A})$ & 1 & & & & & & \\
\hline $\mathrm{H}-1$ (B) & 2 & & 3 & & 2 & 1 & \\
\hline new1 (B) & & & & 1 & & & \\
\hline Bcero / Total & 4 & 3 & 4 & 1 & $\mathbf{2}$ & & \\
\hline
\end{tabular}




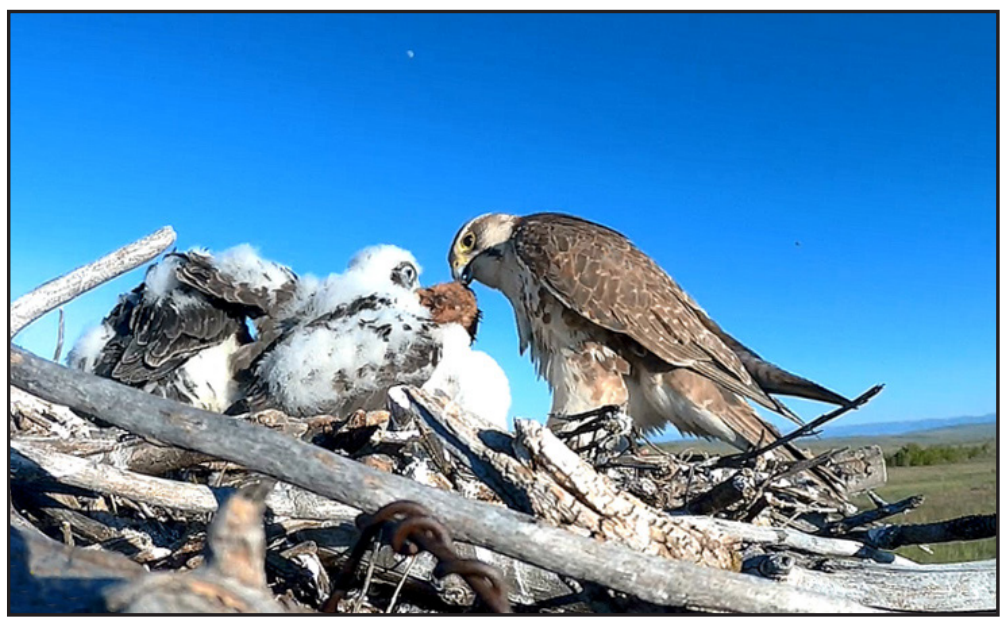

Самка балобана кормит своих и приемных птенцов на 36-й минуте после подсадки. Фото автоматической камеры.

Female feeding nestlings both native and non-native on a 36 minute after introduction non-native nestlings in the nest. Photo by automatic camera.
При наблюдении за результатами искусственной подкормки было показано, что птенцы спокойно реагируют на Аюбую подкормку (суточные цыплята, Ажунгарские хомячки, обыкновенные хомяки, лабораторные крысы) и в возрасте 30 дней начинают пробовать есть самостоятельно. В то же время взрослая самка на этом гнезде кормияа птенцов цыплятами, хомячками и хомяками, но при появлении на гнезде белой крысы не садилась на гнездо в течение нескольких часов, и при кормиении птенцов белых крыс избегала, в то же время серых крыс выносима из гнезда и поедаиа сама.

\section{Мониторинг вылета птенцов}

Круглосуточное видеонаблюдение на гнезде в Республике Алтай показамо, что все выжившие после атаки фрилина птенцы, в возрасте 43-45 дней вылетели и держались на участке, периодически возврашаясь на гнезАо. Позже филином был убит уже лётный птенец из этого выводка (см. ниже).

Проверка гнёзд на платсрормах на экспериментаиьной плошахке в Туве после вылета птенцов показаиа, что все подсаженные птенцы успешно вылетели, но из "Аиких" погибли 3 птенца. Ава птенца погибли на открытой платсорме, устроенной на бетонной опоре в ровной степи в УАалении от искусственных лесонасаждений (выводок из 6 птенцов - 4 нативных и 2 подсаженных): один птенец, начавший оперяться, выпаи из гнезда и умер от голода, так как родители его перестаии кормить под гнездом, второй - уже хорошо метаюший, был убит более крупным пернатым хищником рялом с гнездом. Ещё один нативный птенец погиб в гнезде на платсрорме на тополе в выводке из 7 птенцов (5 нативных и 2 подсаженных). Причина гибели неизвестна, возможно, инфекция или отравление, так как это был уже оперённый и готовый к вылету птенец (аитайского фенотипа и не миацший в выводке), а труп был без признаков истошения.

Таким образом, из сформированных выводков обшей численностью 34 птенца (24 нативных птенца и 10 подсаженных) $\Delta$ о вылета $о$ ожили 30 птенцов, а $\Delta о$ разлёта выводков - 28 птенцов. Обший отход птенцов составия 17,65 \%, выживаемость $-82,35$ \% (табл. 3).

\section{Отслеживание перемещений птен-}

\section{цов после вымета}

В течение нелели после мечения трекера-

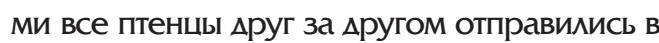
первый полёт и мержаиись вблизи гнезда $\Delta о$ середины июля. ОАнако после 1 июля они уже не трогали оставленную на гнезде еАу - это значит, что пытаиись охотиться самостоятельно и еАы им хватаио.

К сожалению, трекер на "питомниковском" соколе вышел из строя, а "дикого" самца с передатчиком 16 июля сьел фииин тот же самый, который уничтожил его собратьев на гнезде. В итоге в миграцию пошла единственная дикая самка с трекером, которой Аали имя "Учсын".

После вылета из гнезда и $ы$ напацения сримина, птенцы перемешамись по гнездовой территории не далее 4 км от гнезда. МСР самки составил 8,3 км², самца - 5,3 км² (рис. 3).

Отслеживание локаций ночёвки птиц показывает, что они ночевами вместе на одних и тех же скалах $\Delta$ о тех пор, пока не произошло напацение фииина на самца.

После 16 июля (после успешной добычи филином самца), Учсын покинула гнезАовой участок и сушественно расширила

Табл. 3. Выживаемость птенцов баиобана в хоце проекта.

Table 3. Survival of the Saker Falcon nestlings during the project.

\begin{tabular}{|c|c|c|c|c|c|}
\hline & $\begin{array}{l}\text { Tyва } \\
\text { Republic of Tyva }\end{array}$ & $\begin{array}{l}\text { Aлтай } \\
\text { Republic of Altai }\end{array}$ & $\begin{array}{l}\text { BCEIO } \\
\text { TOTAL }\end{array}$ & $\begin{array}{l}\text { Погибли } \\
\text { Mortality }\end{array}$ & $\begin{array}{l}\text { Выжияи } \\
\text { Survived }\end{array}$ \\
\hline Природные птенцы / Natural nestlings & 20 & 4 & 24 & 4 & 20 \\
\hline Подсаженные птенцы / Nestlings from nursery & 7 & 3 & 10 & 2 & 8 \\
\hline BCEГO / TOTAL & 27 & 7 & 34 & 6 & 28 \\
\hline Погибли / Mortality & 3 & 3 & 6 & 17.65 & \\
\hline Выжили / Survived & 24 & 4 & 28 & & 82.35 \\
\hline
\end{tabular}




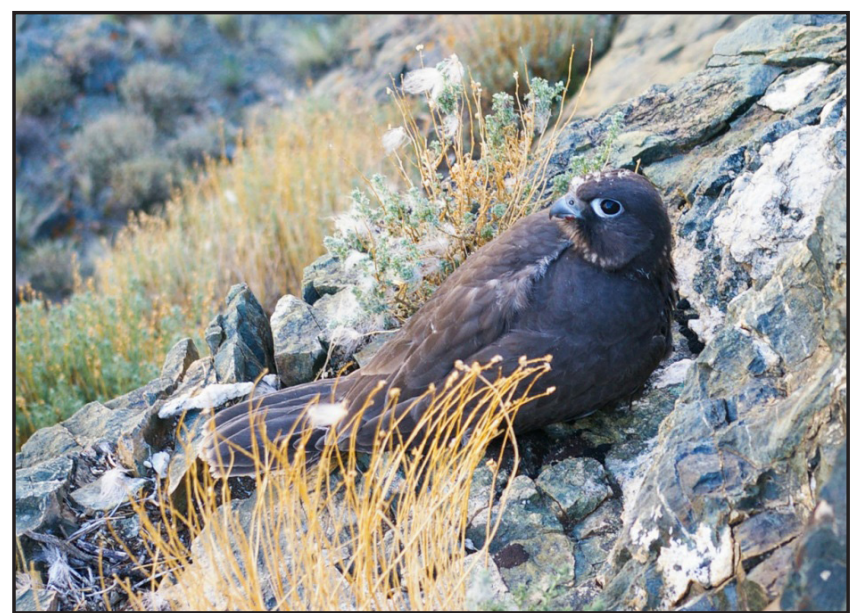

зону своих перемешений. Сначала она перелетела Чуйскую степь с Сайлюгема на Курайский хребет, гле обогнув г. Тобожок вернулась к гнезду, затем отправилась к югу в горы Монголии, удамившись почти на 50 км от гнезда, но снова вернулась обратно, затем полетела к р. Чаган-Узун и опять вернулась к гнезду. В августе Учсын слетала вглубь Баян-Ульгийского аймака Монголии, удаиившись от гнезда на 158 км, но снова вернулась обратно и стала осваивать территорию Сайлюгема, откуда также совершила два 70-километровых вылета мимо Ташанты к югу хр. Чихачева.

За месяц с 16 июля по 11 августа Учсын сушественно расширила область своих перемешений: МСР увеличился с $8 \Delta 08715$ км²,

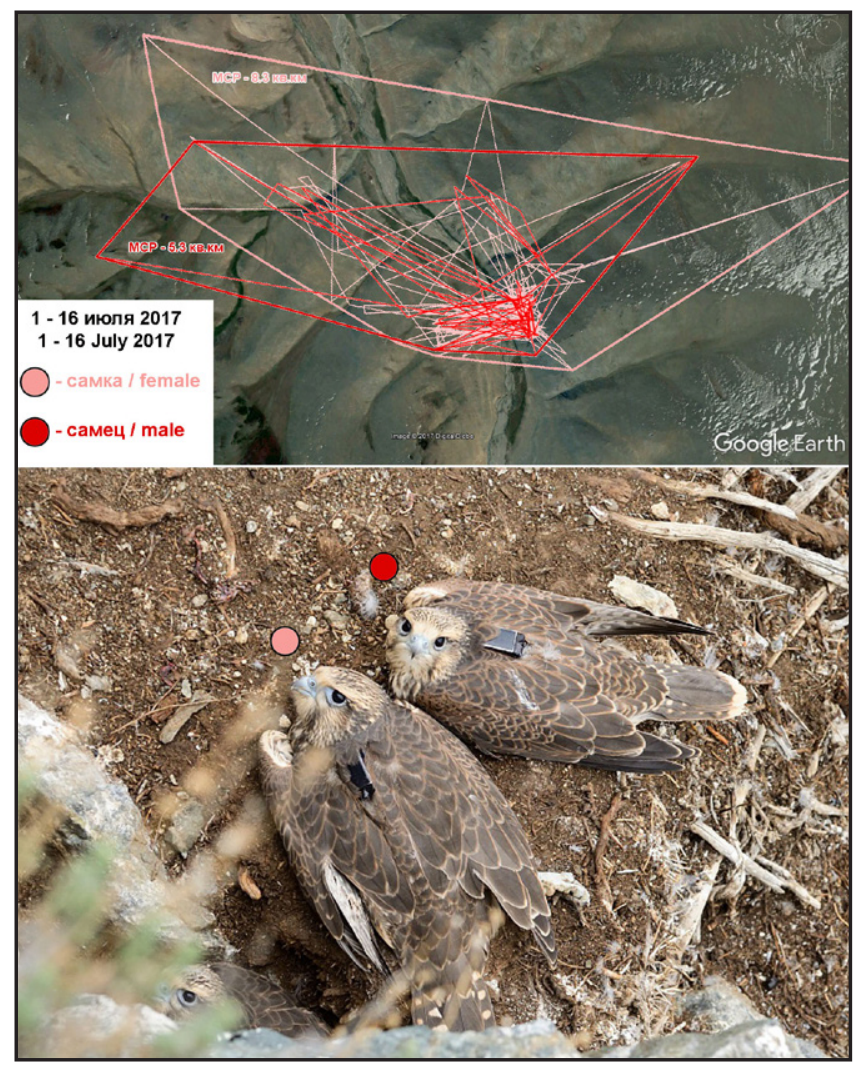

Питомниковский птенец бамобана “амтайского" фенотипа за несколько дней до вылета из гнезда приёмных родителей. Фото Э. Николенко.

Saker Falcon nestling of "Altaic" phenotype from the breeding center few days before leaving the adoptive nest. Photo by E. Nikolenko.

а протяжённость маршрута через точки мокаций составила более 1,5 тыс. км.

В ходе визуаиьных наблюдений за соколами непосредственно на гнездовом участке удамось сротографрировать 2-х молодых бамобанов, но все они были без колец и передатчиков, при этом Учсын всё это время держаиась поблизости в пределах видимости с точек наблюдения, что мы знаем по результатам её спутникового прослеживания. Пятого августа на участок Учсын прилетела молодая птица с трекером, помеченная в Монголии в районе Ульгий. Молодой монгольский балобан преодолел 128 км и осел на гнездовом участке Учсын, где держится Ао 22 августа вкиючительно, причём индивидуаиьные участки, в пределах которых перемешамись оба сокола, перекрываются на 30-36 \% от их плошади (рис. 4).

К 14 августа Учсын переместилась в самую высокогорную часть Юго-Восточного Аитая, где осела на 1,5 нелели восточнее ледового массива г. Найрамдаи (4374 м) на территории Монголии, затем на несколько Аней совершила вылет на территорию Китайского Аитая, удаиившись от последнего постоянного места локации на 125 км, затем вернулась в горы восточнее Найрамлаяа, где продолжала держаться до конца августа. Позже Учсын снова совершила 3-дневный вылет вдоль Монгольского Аитая на 220 км и вернулась обратно к Найрамдаму. В начаме сентября Учсын опять совершила "разведочный" вылет почти на 200 км в сторону Баяннура и снова вернулась обратно.

В перемешениях Учсын достаточно чётко локализуются 2 территории в зоне послегнездовых кочёвок до начаяа миграции,

Рис. 3. Перемешения балобанов, помеченных трекерами, в течение 2-х недель после вылета. На фото птенцы в гнезде на скале в горах А^тая за несколько дней $о$ вылета: самка по имени Учсын (слева) и самец (справа). Фото $\Delta$. Штоля.

Fig. 3. Movements of the Saker Falcon fledglings tagged with trackers in duration of 2 weeks after they fledged from nest. On photo: Saker Falcons tagged with trackers in the nest in the Altai mountains few days before leaving the nest: female named Uchsyn (left) and male (right). Photo by D. Shtol. 

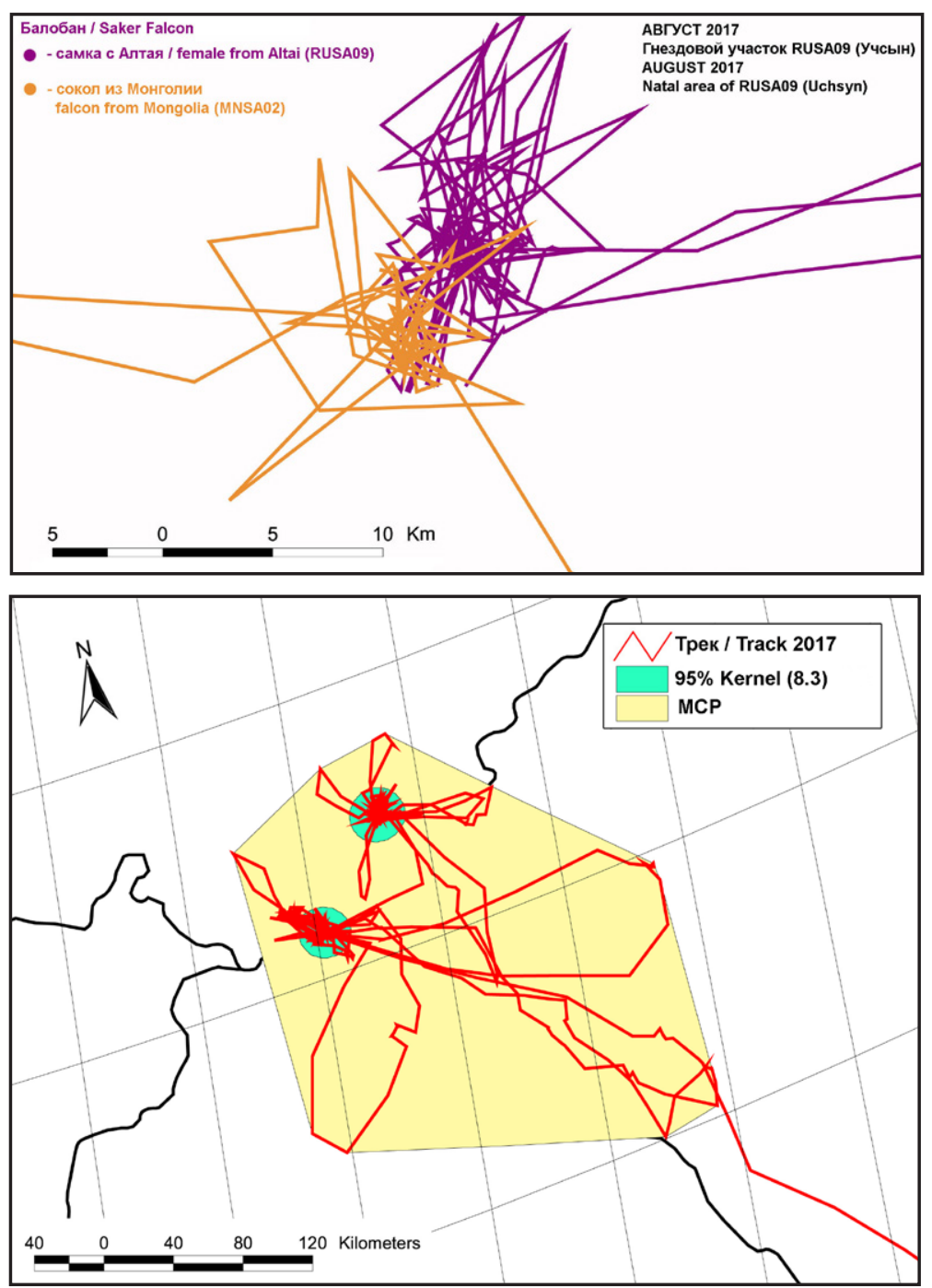

Рис. 5. Перемешения самки балобана (Учсын) в ходе посиегнездовых кочёвок Ао начала активной миграции в 2017 г.

Fig. 5. Movements of the female of Saker Falcon (Uchsyn) during post-nesting period before the active phase of migration in 2017

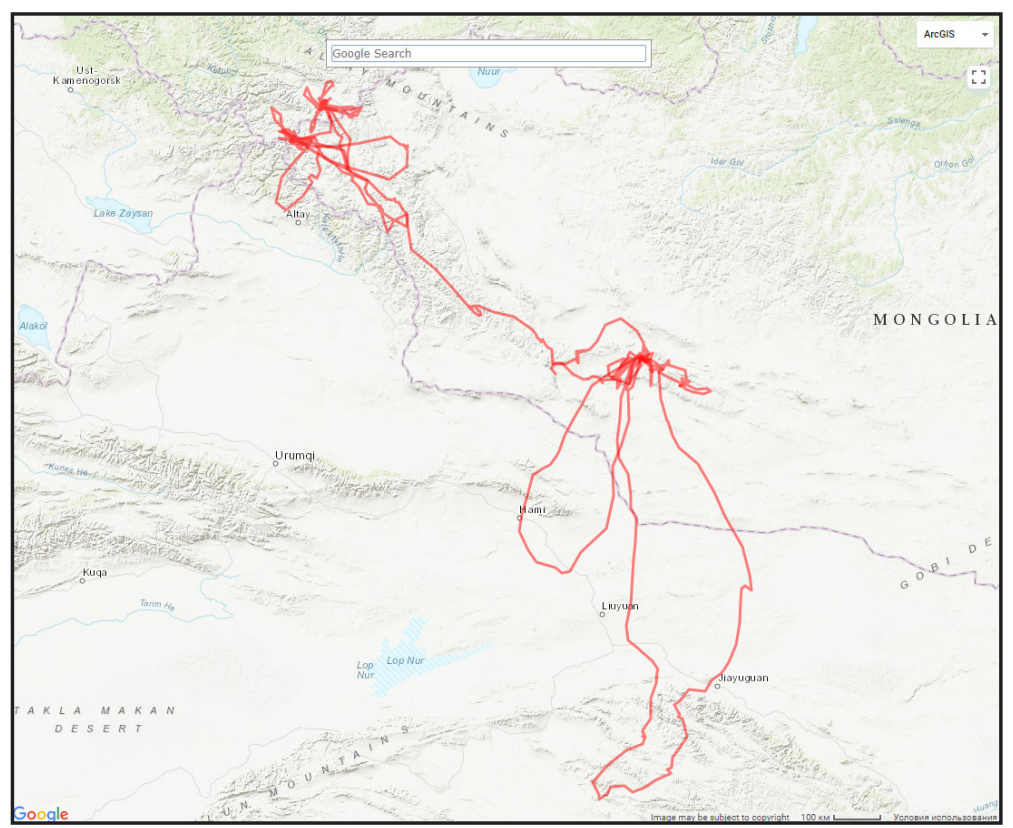

Рис. 4. Перемешения балобана из Монголии и самки по имени Учсын с Алтая в натальной области самки в августе 2017 г.

Fig. 4. Movements of a Saker Falcons from Mongolia and the female named Uchsyn from Russian Altai in the natal area of the female in August 2017.

центры которых удамены 75 км. МСР послегнезАовых перемешений $А$ начаи активной миграции составил 47949,2 км², 95 \% Kernel - 777,77 и

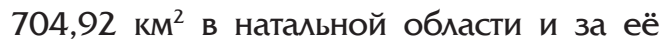
пределами соответственно (рис. 5).

Окончательно покинув горы восточнее Найрамлала 15 сентября, Учсын полетела вАоль Монгольского Алтая на юго-восток и к 22 сентября остановилась в горах ГобиАлтайского аймака, гле осела на миительное время. Отсюда в начале октября она совершила непродолжительный вылет к границе с аймаком Баянхонгор, но вернулась обратно, отсюда же в конце октября она слетала на 450 км в Китай, облетела гору Томурти (4886 м), но вернулась обратно, пролетев 28 октября прямо наА городом Хами и горой Аахей Шань (3970 м).

Учсын продолжила миграцию на юг 20 ноября 2017 г., 21 ноября пересекиа границу Монголии и Китая, а 23 ноября начаяа пересекать хр. Няньшань на пути в Тибет, пройля между пятитысячниками в верховьях р. Шулэхэ. ОАнако в Тибет Учсын так и не полетела и, переночевав на передовых скиацках хребта к северо-запалу от оз. Сяо Кайлама Ху, 26 ноября она повернула на север, прошла прямо нах снеговой шапкой горы Кайлама Шань (5759 м) и 1 декабря вернулась на место зимовки в Монголии.

Полный трек Учсын с 1 июля по 15 мекабря 2017 г. показан на рис. 6. За этот период от трекера Учсын получено 2408 локаций, в среднем по 401,33 $\$ 82,20$ ^окаций в месяц (от 311 локаций в ноябре Ао 513 - в июле). Протяжённость перемешений составила 12127,9 км, в среднем в месяц 2021,31 751,36 км: от 1182,5 км в июле $а$ о 2986,1 км - в сентябре (табл. 4).

$\Delta$ истанция от натаиьной области Ао крайней точки в период зимних перемешений составила 1452 км, азимут - 149 грацусов, этой точки птица Аостигла на 104 день после

Рис. 6. Полный трек самки бамобана (Учсын) с 1 июля по 15 цекабря 2017 г.

Fig. 6. A full track of the female of Saker Falcon (Uchsyn) from July 1 to December 15, 2017. 
Табл. 4. Параметры перемешений самки балобана (Учсын) за 6 месяцев 2017 г.

Table 4. Parameters of movements of the female of Saker Falcon (Uchsyn) during 6 months in 2017.

\begin{tabular}{|c|c|c|c|c|}
\hline $\begin{array}{l}\text { Mecru } \\
\text { Month }\end{array}$ & $\begin{array}{l}\text { Число локаций } \\
\text { Number of locations }\end{array}$ & $\begin{array}{l}\text { Миина трека (км) } \\
\text { Track length (km) }\end{array}$ & $\operatorname{MCP}\left(\mathbf{k m}^{2}\right)$ & $\begin{array}{l}\text { Kernel } 95 \%\left(\mathrm{~km}^{2}\right) \\
{[R, \mathbf{k m}]}\end{array}$ \\
\hline Июль / July & 513 & 1182.5 & 7087.99 & $88.6[2.5]$ \\
\hline Август / August & 485 & 2671.9 & 40076.85 & $\begin{array}{l}3452.6[11.9] \text { (3 clusters: } \\
198.5+1552.2+1701.9)\end{array}$ \\
\hline Сентябрь / September & 399 & 2986.1 & 101272.79 & $\begin{array}{l}4855.7[11.9] \text { (5 clusters: } \\
2088.4+550.9+1198.4+ \\
155.0+863.0)\end{array}$ \\
\hline Октябрь / October & 371 & 1691.8 & 63996.01 & 1626.6 [11.9] \\
\hline Ноябрь / November & 311 & 2325.4 & 164988.28 & 1941.9 [11.9] \\
\hline Декабрь / December & 329 & 1270.3 & 7839.44 & $807.1[6.3]$ \\
\hline $\begin{array}{l}\text { ИTOTO } 6 \text { мec. } \\
\text { TOTAL } 6 \text { months }\end{array}$ & 2408 & 12127.9 & 574720.53 & $\begin{array}{l}5517.8 \text { [11.9] (3 clusters: } \\
1738.5+1551.5+2227.8)\end{array}$ \\
\hline$M \pm S D$ в мec. / per month & $401.33 \pm 82.20$ & $2021.31 \pm 751.36$ & $64210.23 \pm 60914.58$ & $2128.75 \pm 1754.13$ \\
\hline
\end{tabular}

того как покинула натаиьную область и на 71-й день после начаиа активной миграции. Аистанция от натаиьной области $А$ основной области зимовки, лежашей в горах Монгольского Аитая, составила 738 км, азимут - 125 грахусов. МСР зимних перемешений с учётов маршрута в Китай - 283485,34 км², $95 \%$ Kernel - 10616,16 км², МСР основной области зимовки в монгольском Аитае - 23406,71 км², $95 \%$ Kernel - 642,82 км² (рис. 7).

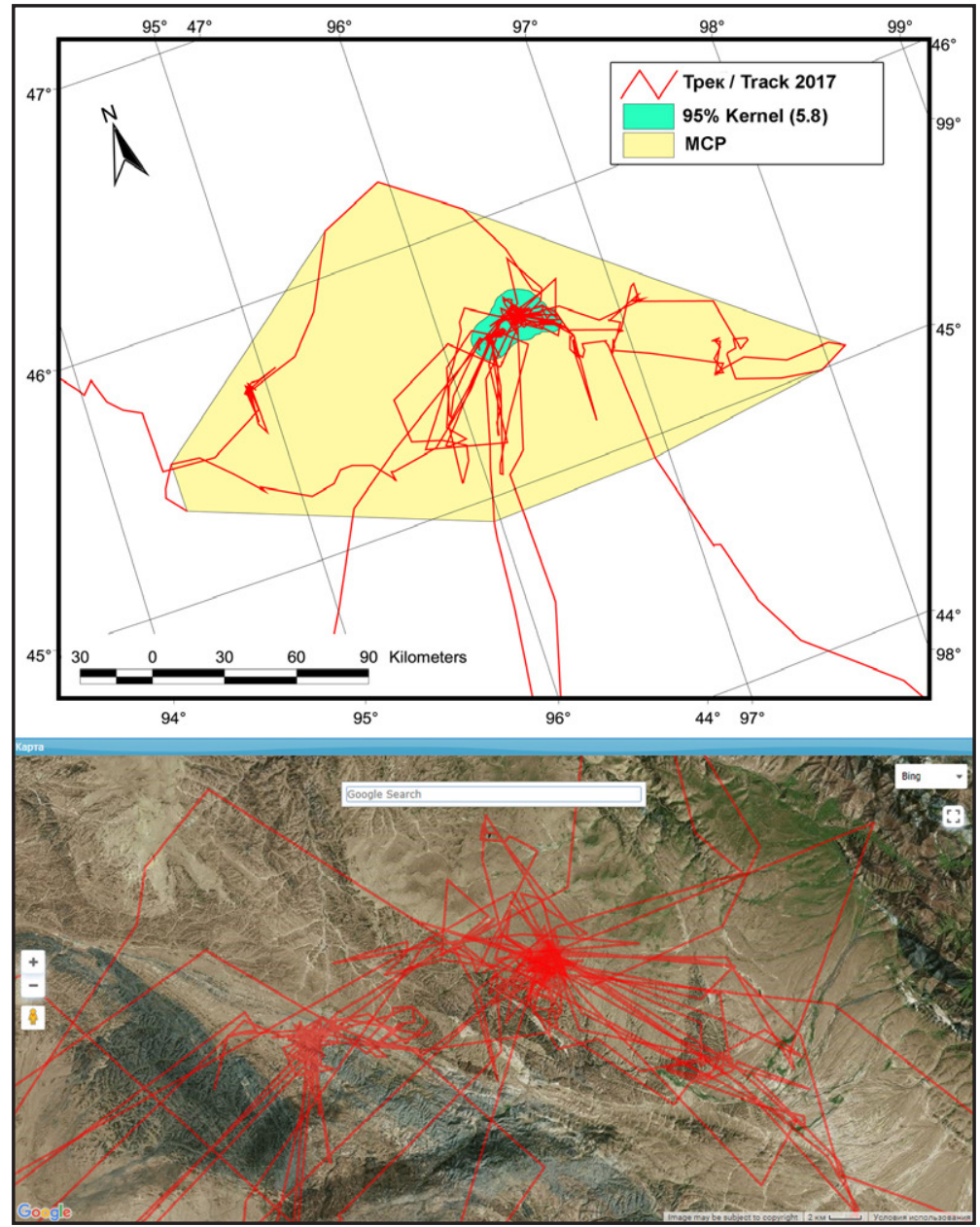

\section{Выводы}

1. Подсацка птенцов балобана в естественные выводки на гнёздах в дикой природе - хороший способ их интеграции в Аикую природу; при организации полкормки - даже в условиях бескормицы. В условиях хорошей кормовой базы возможно выживание выводков из 6 птенцов без их Аополнительной подкормки и ушерба мия млахших нативных птенцов (прослеживание с помошью трекера млацшей самки в выводки показамо успешную миграцию и зимовку этой птицы).

2. Территория реамизации проекта Аолжна быть удалена от жилья и мест посешения Аюдьми, чтобы снизить фрактор случайного беспокойства и привлечения внимания ловцов.

3. При подсалке необходимо тщательно подходить к выбору гнёзд, стараясь выбирать те, которые удалены от гнёзд крупных хишников, особенно фрилина.

4. Есии выбор гнезда в удамении от гнёзд крупных хишников невозможен, то их выводки необходимо также подкармиивать, как выводки соколов, чтобы искиючить хищничество по причине недостатка питания. Также можно организовать отпугивание филина от гнезда балобана в тёмное время суток с помошью проблесковых маяков с Аетектором Авижения, что, по крайней мере, зашитит птенцов $А$ вылета из гнезда.

5. Ая крупных выводков (6-7 птенцов) желательно формировать гнездовую плат-

Рис. 7. Перемешения самки балобана (Учсын) в области зимовки в 2017 г.

Fig. 7. Movements of the female of Saker Falcon (Uchsyn) in the wintering area in 2017. 


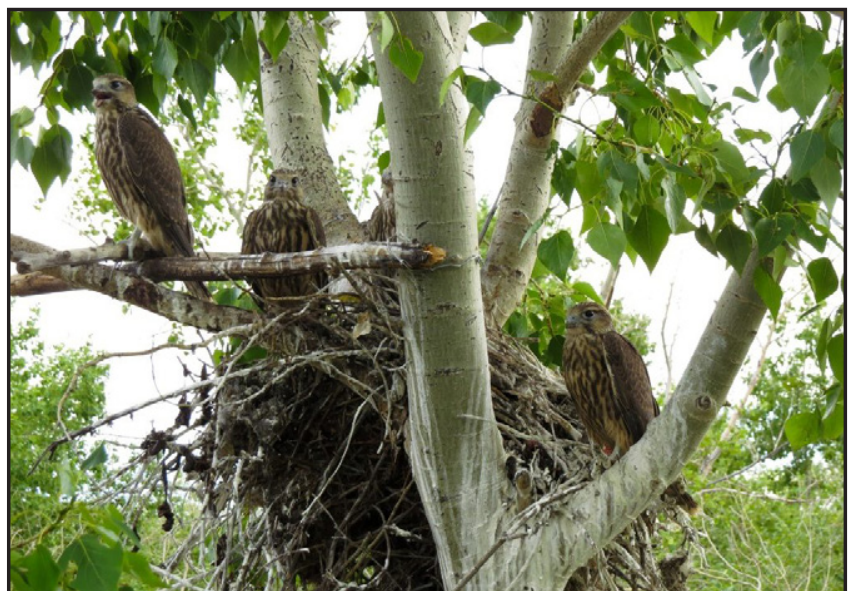

Все птенцы баиобана, вкцючая птенца из питомника, успешно Аоросии до вылета из гнезда.

Фото А. Куксина.

Nest with successfully grown and fledged native and adoptive nestlings.

Photo by A. Kuksin.
Команда иссиедователей под гнезАом балобана, в которое подсажены птенцы из питомника. Фото А. Куксина.

$A$ research team under the Saker's nest with nestlings from the breeding center. Photo by A. Kuksin. форму диаметром не меньше 1,2 м с бортами, искиючающими выпацение птенцов, закрытую сверху скачой, кроной дерева или искусственной конструкцией ммя большей зашиты от крупных хишников и непогоды.

6. Аия слежения за ситуацией на гнезде после подсалки птенцов желательно организовать видеотрансляцию, что позволит экстренно принять меры в случае угрозе жизни птенцов.

7. Полученные нами результаты полностью согласуются с вылвинутым ранее предпоможением (Карякин, 2011), что “аитайская" морсра формируется в зоне интерградации обыкновенного баиобана, относяшегося к западной гапиогруппе, и восточных подви$\triangle$ Ов (F. c. milvipes и F. c. progressus), относяшихся к восточной гаплогруппе, к которой относится и кречет. Именно поэтому по минии самок птицы "аитайского" фенотипа могут подразделяться на $\Delta в е$ гаплогруппы, присутствуюшие в Аитае-Саянском регионе, а в Аругих регионах, гле гнездяшиеся птицы относятся к ОАной митохонАриаиьной гапиогруппе (Запацный и Центраиьный Казахстан, мибо Центраиьная Монголия и Тибет), «аитайский" фенотип не проявляется.

8. Поскольку “алтайский" балобан в настояшее время практически исчез в природных местообитаниях, восстановление

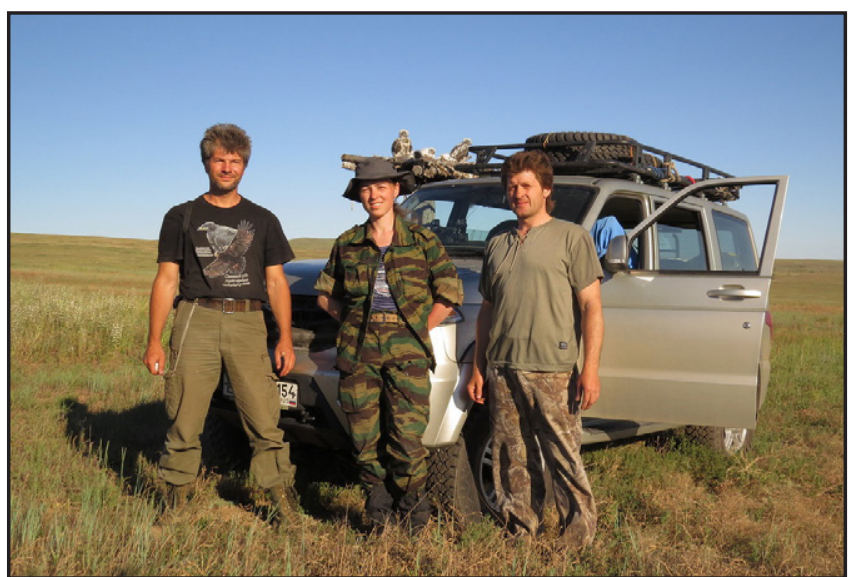

его численности в Алтае-Саянском регионе посредством выпуска птиц, вырашенных в питомниках, является актуамьной задачей с точки зрения восстановления биоразнообразия природных популяций. Однако, поскольку при скрешивании фенотипически чистых аитайских бамобанов в потомстве появляются птицы, имеюшие фенотипы Аругих морф, требуются Ааиьнейшее изучение природы возникновения тёмных алтайских балобанов в зоне интерграцации трёх подвидов бамобанов в Аитае-Саянском регионе - с помошью молекулярно-генетических методов.

\section{Благодарности}

Авторы благодарят за помошь в работе заместителя директора по НИР национального парка "Сайлюгемский" $\Delta$. Махикова, сотрудников нацпарка "Сайлюгемский", заместителя директора по НИР заповедника "Убсунурская котловина» А. Куксина, волонтёров $\Delta$. Зимина, М. Пчельникова и $\Delta$. Штоля. Отдельная благодарность Р. Пфеерферу, вАохновившему авторов на реализацию проекта по восстановлению «алтайского» бамобана в его историческом гнездовом ареале, и М. Проммеру, благодаря помоши которого удалось приобрести трекеры мия мечения соколов. Также авторы благодарят за поццержку проекта The Altai Project/ Earth Island Institute, Алтае-Саянское отделение WWF России, ФонА "Мир вокруг тебя" корпорации "Сибирское зАоровье", компанию «Ecotone" и Международную ассоциацию сокольников (IAF).

\section{\итература}

Андреенков О., Андреенкова Н., Бакка С., Барашкова А., Бартошук К., Бредихина Н., Важов С., Аениссов А., Аеметер И., Аонгак Н., Карякин И., Куксин А., Маер В., Николенко Э., Писаревский С., Шнайдер Е., Эбель А. Балобан (Falco cherrug). - Пернатые хишники Мира (Веб-ГИС «Фаунистика»). 2017. [Andreenkov O., Andreenkova N., Bakka S., Barashkova A., Bartoszuk K., Bredikhina N., Vazhov S., Denissov A., Demeter I., Dongak N., Karyakin I., Kuksin A., Mayer V., Nikolenko E., Pisarevsky S., Shnayder E., Ebel A. Saker Falcon (Falco cherrug). - Raptors of the World (Web-GIS "Faunistics"). 2017.] URL: http://raptors.wildlifemonitoring.ru Аата обрашения: 15.12.2017.

Аементьев Г.П. Отряд хищные птицы: Асcipitres или Falconiformes. - Птицы Советского Союза. Т. 1. М.: Сов. Наука, 1951. С. 70-341. [Dementiev G.P. Birds of prey: Accipitres or Falconiformes. - Birds of the Soviet Union. Vol. 1. Moscow, 1951: 70-341. (in Russian)]. URL: http:// rrrcn.ru/ru/archives/14389 Аата обрашения: 15.12.2017. 
Аементьев Г.П., ШагАарсурен А. О монгольских бамобанах и таксономическом положении алтайского кречета. - Исследования по фауне Советского Союза (птицы). М., 1964. С. 3-37. [Dementiev G.P., Shagdarsuren A. About Mongolian Saker Falcon and Taxonomic Status of Altai Gyrfalcon. - Studies on the fauna of the Soviet Union (birds). Moscow, 1964: 3-37 (in Russian).]

Карякин И.В. Пернатые хишники (методические рекомендации по изучению соколообразных и совообразных). Нижний Новгород: Издательство «Поволжьее, 2004. 351 с. [Karyakin I.V. Raptors (manuals on surveys of birds of prey and owls). Nizhniy Novgorod: Publishing House "Povolzhie", 2004: 1-351 (in Russian).]. URL: http://rrrcn.ru/ru/ archives/11151 Аата обрашения: 15.12.2017.

Карякин И.В. Популяционно-подвидовая структура ареала бамобана. - Пернатые хищники и их охрана. 2011. № 21. С. 116-171. [Karyakin I.V. Subspecies Population Structure of the Saker Falcon Range. - Raptors Conservation. 2011. 21: 116-171.] URL: http://rrrcn.ru/ru/archives/18913 Аата обрашения: 15.12.2017.

Карякин И.В., Мевин А.С., Мошкин А.В., Николенко Э.Г. Бамобан в России и Казахстане. XIV Международная орнитологическая консеренция Северной Евразии. II. Аокиады / Отв. ред. А.Ф. Ковшарь. Амматы, 2015. С. 473-530. [Karyakin I.V., Levin A.S., Moshkin A.V., Nikolenko E.G. Saker Falcon in Russia and Kazakhstan. - XIV International Ornithological Conference of Northern Eurasia. II. Oral presentations. Almaty, 2015: 473530.] URL: http://rrrcn.ru/ru/archives/25433 Аата обрашения: 15.12.2017.

Карякин И.В., Николенко Э.Г. Результаты проекта по восстановлению мест гнездования хишных птиц в Республике Тыва, Россия. - Пернатые хишники и их охрана. 2011. № 21. С. 14-83. [Karyakin I.V., Nikolenko E.G. Results of the Project for Restoration of Nesting Places of the Birds of Prey in the Republic of Tyva, Russia. - Raptors Conservation. 2011. 21: 14-83.] URL: http://rrrcn.ru/ru/ archives/14336 Аата обрашения: 15.12.2017.

Карякин И.В., Николенко Э.Г., Шнайдер Е.П. Результаты мониторинга популяции балобана в Алтае-Саянском регионе в 2014 году, Россия. - Пернатые хищники и их охрана. 2014. № 29. C. 58-76. DOI: $10.19074 / 1814-8654-$ 2014-29-58-76. [Karyakin I.V., Nikolenko E.G., Shnayder E.P. Results of Monitoring of the Saker Falcon Population in the Altai-Sayan Region in 2014, Russia. - Raptors Conservation. 2014. 29: 58-76. DOI: 10.19074/1814-8654-2014-2958-76.] URL: http://rrrcn.ru/ru/archives/25729 $\triangle$ ата обрашения 15.12.2017.

Ковач, А., Уимиамс, Н.П., Гэлбрэйт, К.А. Межнународный План Аействий по балобану Falco cherrug (SakerGAP), вкиючая систему менеджмента и мониторинга мяя сохранения вида. МоВ по Хищным Птицам Технический Аокумент Номер 2. КМВ Техническая Серия Номер 31. Координационный Центр - КМВ Хишные Птицы MoB, Абу-Ааби, Объединенные Арабские Эмираты, 2014. 160 с. [Kovacs, А.,
Williams, N.P. and Galbraith, C.A. Saker Falcon Falco cherrug Global Action Plan (SakerGAP), including a management and monitoring system, to conserve the species. Raptors MOU Technical Publication No. 2. CMS Technical Series No. 31. Coordinating Unit - CMS Raptors MOU, Abu Dhabi, United Arab Emirates, 2014: 1-206.] URL: http://www.cms.int/dugong/sites/default/ files/document/SakerGAP_r_0.pdf $\triangle$ ата обрашения 15.12.2017.

Мошкин А.В. Обосновано ки научно снижение природоохранного статуса бамобана? - Пернатые хишники и их охрана. 2010. №19. C. 37-74 [Moshkin A.V. Is there any scientific basis for decreasing the conservation status of the Saker Falcon? - Raptors Conservation. 2010. 19: 37-74]. URL: http://rrrcn.ru/ru/archives/19319 $\triangle$ ата обрашения 15.12.2017.

Николенко Э.Г., Карякин И.В. Распространение, численность и статус балобана (Falco cherrug) в Республике Тыва. - Современное состояние редких видов растений и животных Республики Тыва: материаны Всероссийской научно-практической конференции (28-29 апреля 2016 года) / отв. ред. У.В. Ондар. Кызыл: Иза-во ТувГУ, 2016. С. 99-105. [Nikolenko E.G., Karyakin I.V. Distribution, number and status of Saker Falcon (Falco cherrug) in the Republic of Tyva. - The current state of rare plant and animal species of the Republic of Tyva: materials of the All-Russian Scientific and Practical Conference (April 28-29, 2016) / U.V. Ondar (Ed.). Kyzyl, 2016: 99-105 (in Russian).] URL: http://rrrcn.ru/wp-content/uploads/2016/09/Nikolenko-Karyakin-Saker2016. pdf Аата обрашения 15.12.2017.

Николенко Э.Г., Карякин И.В., Аевин А.С. Корни проблемы сокрашения численности бамобана и пути её решения в рамках Глобального плана действий по бамобану на примере России и Казахстана. - Пернатые хишники и их охрана. 2014. № 29. C. 18-38. [Nikolenko E.G., Karyakin I.V., Levin A.S. Root causes of the decreasing in numbers of the Saker Falcon and ways of its decision within the Saker Falcon Global Action Plan in Russia and Kazakhstan. - Raptors Conservation. 2014. 29: 18-38.] DOI: 10.19074/18148654-2014-29-18-38. URL: http://rrrcn.ru/ru/archives/25759 Аата обрашения 15.12.2017.

Николенко Э.Г., Карякин И.В., Шнайдер Е.П. Результаты многолетнего проекта по привлечению хишных птиц на искусственные гнездовья в Туве. - Хишные птицы Северной Евразии. Проблемы и ацаптации в современных условиях: материалы VII Международной конференции РГСС, г. Сочи, 19-24 сентября 2016 г. / Отв. реА. В.П. Белик. Ростов н/А.: изА. Южного феАераиьного университета, 2016. С. 438-443. [Nikolenko E.G., Karyakin I.V., Shnayder E.P. The results of a multi-year project for attracting of raptors to artificial nests in Tuva. - Birds of Prey in the Northern Eurasia: Problems and adaptations in current environment: Proceedings of the VII International Conference on Birds of Prey and Owls of Northern Eurasia, Sochi, 19-24 Septem- 
ber 2016 / V.P. Belik Ed. Rostov-on-Don, 2016: 438-443 (in Russian).] URL: http://rrrcn.ru/wpcontent/uploads/reports/sochi2016/Nikolenkoetal2016.pdf Аата обрашения 15.12.2017.

Образцы колец и цветовые схемы. - Российская сеть изучения и охраны пернатых хишников. 2017. [Tуреs of Rings and Colour Schemes. - Russian Raptor Research and Conservation Network. 2017]. URL: http://rrrcn.ru/ringing/ obraztsyi-kolets/3 Аата обрашения 15.12.2017.

Пфесффер $P$. К вопросу о географической изменчивости баиобанов. - Пернатые хишники и их охрана. 2009. № 16. С. 68-95. [Pfeffer $R$. About Geographic Variances of the Saker Falcon. - Raptors Conservation, 2009. 16: 68-95.] URL: http://rrrcn.ru/ru/archives/19501 Аата обрашения 15.12.2017.

Стартоваи первый проект по возрождению сокола-балобана в Южной Сибири. - Российская сеть изучения и охраны пернатых хищников. 2017. [The first project to revive the Saker Falcon in Southern Siberia was launched. - Russian Raptor Research and Conservation Network. 2017.] URL: http://rrrcn.ru/ru/archives/28754 Аата обрашения 15.12.2017.

Степанян А.С. Конспект орнитологической фауны СССР. Москва «Наука", 1990. 727 с. [Stepanyan L.S. Conspectus of the ornithological fauna of the USSR. Moscow, 1990: 1-727 (in Russian)].

Сушкин П.П. Птицы Советского Алтая и прилежаших частей Северо-Запанной Монголии. M.-ᄉ., 1938. T. 1.316 c. T. 2. 434 c. [Sushkin P.P. Birds of the Soviet Altai and adjacent parts of the North-Western Mongolia. M.-L., 1938. T. 1: 316, T. 2: 434 (in Russian).]

Burnham W., Cade T.J. Return of the Peregrine. The Peregrine Fund, 2003: 1-394.

Caccamise D.F., Hedin R.S. An aerodynamic basis for selecting transmitter loads in birds. Wilson Bulletin. 1985. 97 (3): 306-318. URL: https://sora.unm.edu/sites/default/files/journals/wilson/v097n03/p0306-p0318.pdf Аата обрашения: 12.12.2017.

Fridolfsson A., Ellegren $H$. A simple and universal method for molecular sexing of nonratite birds. - Journal of Avian Biology. 1999. 30 (1): 116-121. DOI: 10.2307/3677252 URL: http://www.jstor.org/stable/3677252 Аата обрашения: 10.12.2017.

Horak $P$. Reintrodukce umele odchovanych mladat raroha velkeho (Falco cherrug) do volne prirody. - Dravci 1985. Zbornik prednasek, Prerov, 1987. 239-243 pp. [Horak P. Reintroduction of juvenile Saker Falcons (Falco cherrug) into wildlife. - Birds of prey 1985 / J. Sitko, P. Trpбk (Eds.). Prerov, 1987: 239-243 (In Czech).] URL: http:// www.tkv.cz/pdf/sbornik/dravci/1985_239_243. pdf $\triangle$ ата обрашения: 12.12.2017.

Hooge P.N., Eichenlaub B. Animal movement extension to ArcView, Version 1.1.: Alaska Science Center - Biological Science Office, U.S. Geological Survey, Anchorage, AK, USA, 1997. URL: https://gcmd.nasa.gov/records/USGS_animal_mvmt.html Аата обрашения: 12.12.2017.
Hooge P.N., Eichenlaub B., Solomon E.K. Using GIS to analyze animal movements in the marine environment. - Spatial processes and management of marine populations. University of Alaska Fairbanks, 2001: 37-51. URL: ftp:// ftp.unine.ch/Bouzelboudjen/cisarovsky/Cisarovsky/Extension_AV_HRE_AnmalMovement2/ AnimalMovement2/anim_mov_useme.pdf $\triangle$ ата обрашения: 12.12.2017.

GBIF. Falco cherrug J.E. Gray, 1834. GBIF Occurrence Download [Электронный ресурс] - GBIF. org. 2017. DOI: doi.org/10.15468/dl.kh51zd URL: http://doi.org/10.15468/dl.kh51zd $\triangle$ ата обрашения 15.12.2017.

Kenward R. A manual of wildlife radio-tagging. Academic Press, London, 2001: 1-311.

Muller M.G. The Late Sheikh Zayed Falcon Release Program (SZFR). - Saker Falcon Task Force. Stakeholders' Action Planning Workshop. 10 September 2013. Abu Dhabi Falcon Hospital, 2013. URL: http://www.cms.int/sites/default/ files/document/cms-raptors_stf-ws_pr13_mueller.pdf Аата обрашения 15.12.2017.

Nittinger F., Gamauf A., Pinsker W., Wink M., Haring $E$. Phylogeography and population structure of the Saker Falcon (Falco cherrug) and the influence of hybridization: mitochondrial and microsatellite data. - Molecular Ecology. 2007. № 16. P. 1497-1517. DOI: 10.1111/j.1365294X.2007.03245.x URL: http://dx.doi. org/10.1111/j.1365-294X.2007.03245.X Аата обрашения 15.12.2017.

Nowak Z., Sielicki M. Genetic variability of the Peregrine Falcon (Falco peregrinus peregrinus) intended for reintroduction in Poland. - 4th International Peregrine Conference. Abstract book (27 September - 1 October 2017, Herman Otty Conference Centre, Budapest). Budapest, 2017. P. 33.

Ragyov D., Dixon A., Kowalczyk K. Re-introduction of the saker falcon to Bulgaria, SouthEasr Europe. - Global Re-introduction Perspectives: Additional case-studies from around the globe / P.S. Soorae (Ed.). IUCN / SSC Re-introduction Specialist Group, Abu Dhabi, UAE, 2010: 143-146.

Ragyov D., Koshev Y., Kmetova E., Gradev G., Stoyanov G., Stoev I., Marinov D. Preparatory activities for Saker Falcon (Falco cherrug) reintroduction in Bulgaria: habitat management and electrocution risk assessment. - Aquila. 2012. 119: 91-103. URL: http://sakerlife2.mme.hu/ sites/default/files/Aquila-119-108-Ragyov.pdf Аата обрашения 15.12.2017.

RRRCN. Raptors of the World. Version 1.3. Sibecocenter LLC. Occurrence Dataset. - GBIF. org. 2017. DOI: 10.15468/fggsfn URL: https:// doi.org/10.15468/fggsfn Аата обрашения 15.12.2017.

Saker Falcon - Reintroduction in Bulgaria. - International Wildlife Consultants Ltd.: specialising in green solutions. 2012. URL: http://www. falcons.co.uk/conservation.asp?id=239 обрашения 15.12.2017. 